\title{
Cape Verde Frontal Zone
}

\author{
Walter ZenK, ${ }^{*}$ Birgit Klein* and Michael Schröder* $\dagger$
}

(Received 12 May 1989; in revised form 12 June 1990; accepted 21 June 1990)

\begin{abstract}
The term Cape Verde Frontal Zone is introduced to characterize the southeastern corner of the subtropical gyre circulation in the North Atlantic Ocean far west of the upwelling area off the Mauretanean shelf. Two water mass fronts, one overlying the other, are identified with a quasi-synoptic set of CTD- $\mathrm{O}_{2}$ and nutrient data from November 1986. In the warm water sphere we encounter North and South Atlantic Central Water (NACW/SACW) superimposed on extensions of Mediterranean outflow and Antarctic Intermediate Water. The Central Water Boundary, as the separator of NACW from SACW, represents the southeastern side of the Canary/North Equatorial Current system. It acts as a barrier between the well-ventilated, nutrient-poor inner part of the basin-wide circulation of the North Atlantic and the shadow zone with its lowly oxygenated and nutrified cross-equatorial influx. Year-long current meter records, having fluctuations over typical time scales of 50-90 days, attest to the highly variable nature of the Cape Verde Frontal Zone. Incidentally, we observe in the data an intrathermocline eddy, called Meddy BIRGIT, which has a double maximum in the vertical salinity structure. Simultaneous Lagrangian observations by Richardson et al. (1989, Journal of Physical Oceanography, 19, 371-383) confirm the expected anticyclonic motion of this salt lens, which must have travelled without significant mixing for at least $2500 \mathrm{~km}$ from its likely generation region in the Gulf of Cadiz.
\end{abstract}

\section{INTRODUCTION}

IN November 1986 the Institut für Meereskunde, Kiel, conducted a hydrographic survey in the southern Canary Basin off northwestern Africa, the first visit to the region by the new

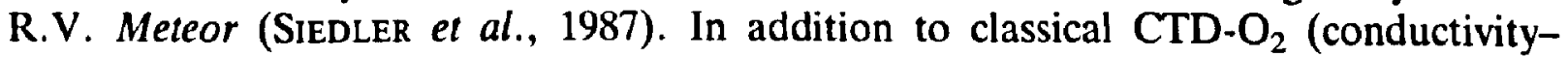
temperature-depth-dissolved oxygen) and hydrochemical work, long-term current meter moorings were deployed. Most of the hydrographic data and current meter time series from this "Kapverde-Expedition" are presented here. They allow for a detailed description of water mass composition and circulation features in the southeastern portion of the subtropical North Atlantic.

In the area off the northern Mauretanean shelf $\left(23^{\circ} \mathrm{N}\right)$ the southwest-flowing Canary Current departs from the continental slope, undergoes large spatial and temporal variations, and later forms the beginning of the westward-flowing North Equatorial Current (EMERY et al., 1987). In the southeastern corner of the subtropical gyre circulation, i.e. equatorward of the Canary Current, there is a hydrographic region where thermocline waters do not directly participate in the general basin-wide circulation of the North Atlantic. Because this area is believed to be excluded from seasonal ventilation at

\footnotetext{
*Institut für Meereskunde an der Universität Kiel, Düsternbrooker Weg 20, 2300 Kiel 1, Germany.

$\dagger$ Alfred-Wegener-Institut für Polar- und Meeresforschung, Columbusstraße, 2850 Bremerhaven, Germany.
} 
northern mid-latitudes (LuYTen et al., 1983; THIELE et al., 1986), it has been called the "shadow zone".

On the northern side of the shadow zone lies the Central Water Boundary (CWB), a major thermocline discontinuity separating the North and South Atlantic Central Water (NACW/SACW) masses (HAGEN, 1985; EMERY and MeINCKE, 1986), which is itself highly variable in time and space. This region, for which we introduce the term "Cape Verde Frontal Zone", is characterized by upper-level horizontal salinity gradients as sharp as 0.9 psu (practical salinity unit) per $10 \mathrm{~km}$. At mid-depth another important front in this region is found: the boundary between the southern extension of the Mediterranean Water (MW) tongue and the northward-propagating Antarctic Intermediate Water (AAIW). Upwelling phenomena near the continental shelf and the weakly stratified North Atlantic Deep Water (NADW) beneath the MW further contribute to the complexity of this remarkable hydrographic region.

Our main objective for the "Kapverde-Expedition" was to investigate the large-scale water mass properties and their distribution and advection far west of the continental slope. In the past, a number of surveys in connection with upwelling studies have taken place near the shelf edge (Barton and Hughes, 1982; Manriquez and Fraga, 1982; MitTelstaedT, 1983; Barton, 1987). The question as to whether the CWB represents a barrier for newly ventilated recirculating water masses, however, can only be answered with synoptic surveys connecting deep basin with shelf edge hydrography

In Section 2 we present hydrographic and current meter data sets from Meteor cruise 4. This is followed by a discussion of the observed spatial structure of the Cape Verde Frontal Zone divided into upper and lower thermocline water masses. In Section 4 we show geostrophic currents and transports, followed by the direct current measurements. Section 6 discusses a singularity (meddy) in the hydrographic data. Finally, Section 7 summarizes our synoptic observations.

\section{NEW DATA}

Assuming a general northeast-southwest direction of the CWB, we made two parallel hydrographic sections orthogonal to the Cape Verde Frontal Zone (Fig. 1). The whole survey took place from 3 October to 6 December 1986. The following analysis of the vertical distribution of water masses is restricted to the synoptic sections $A$ and $B$, which were separated by about $250 \mathrm{~km}$. Data from the meridional section on $27.0^{\circ} \mathrm{W}$ and all other southern positions are used for horizontal property distributions.

Station spacing ranged from 30 to $100 \mathrm{~km}$, with measurements generally made to at least $2000 \mathrm{dbar}$ depending on the available time. A Neil Brown MK3 CTD- $\mathrm{O}_{2}$ unit was used together with a rosette having twelve 10 -litre Niskin bottles. Water samples were utilized for calibration checks of the CTD- $\mathrm{O}_{2}$ system and for nutrient analysis. In situ calibration procedures and error analyses are described by SIEDLER et al. (1987). After editing, the data were smoothed with a moving average and linearly interpolated to 2 dbar. Oxygen titrations were carried out with an estimated accuracy of $\pm 0.01 \mathrm{ml} \mathrm{l}^{-1}$. The analytical precisions for nitrate, phosphate and silicate are of order $( \pm 0.01, \pm 0.01, \pm 0.05) \mu \mathrm{mol}$ $\mathrm{dm}^{-3}$ (GraßhoFf, 1976).

Selected year-long current and temperature time series from a nominal depth of $400 \mathrm{~m}$ are presented in Section 5. Logistical details on mooring locations, instrument performance, and data reduction can be found in reports by Siedier (1986a), Stedler et al. (1987) 


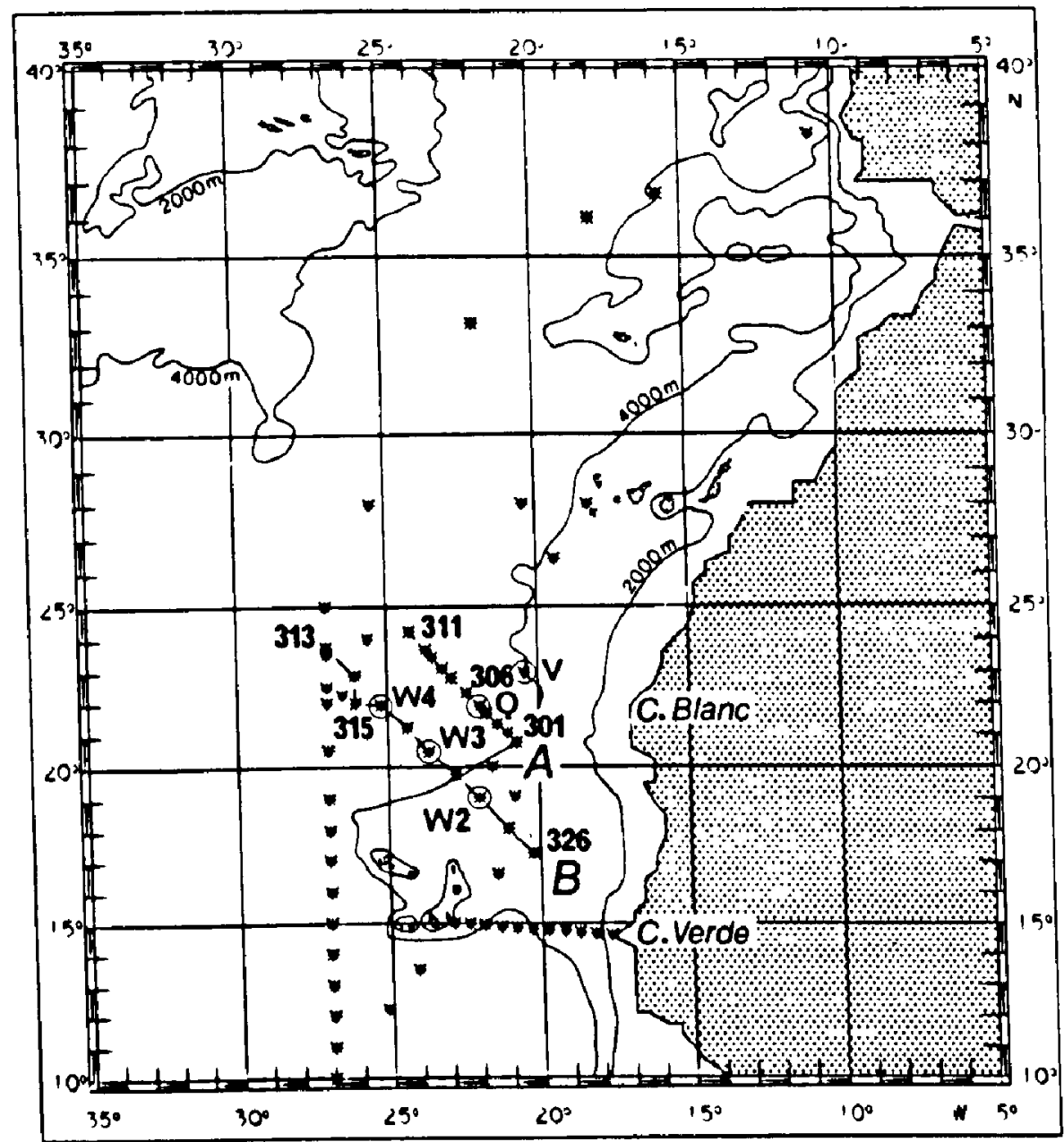

Fig. 1. Station map of the "Kapverde-Expedition", Meteor cruise 4. Sixty-seven CTD-O stations and five mooring positions (V, Q, W4, W3, W2) were visited in November 1986. Sections $A$ and $B$ were particularly designed to observe the separation of the Canary Current from the continental shelf off West Africa.

and Müller et al. (1988). Mooring positions are indicated by circles in Fig. 1 and are summarized in Table 1.

Mooring $\mathrm{V}$ was deployed at a location where bottom topography suggests the separation of the Canary Current as an eastern boundary current from the continental rise. Mooring $Q$ was situated in the centre of section $A$, while moorings $W 2, W 3$, and $W 4,220 \mathrm{~km}$ apart, were aligned parallel to section $B$. The aim of mooring line $W$ was to record the variability of a topographically unconstrained Canary Current and associated spatial shifts of the Cape Verde Frontal Zone.

While most instruments on $\mathrm{V}$ and $\mathrm{W} 4$ worked properly and the mooring rigs stayed intact, we encountered unexpected problems with $\mathrm{Q}, \mathrm{W} 2$ and $\mathrm{W} 3$. In all three cases the uppermost buoyancy elements, together with the top current meter at $200 \mathrm{~m}$, were lost due to fish bite after about 3 months. After the loss of the subsurface flotation, the dynamic stability of the remaining moorings became significantly diminished. As a consequence, we must be cautious when interpreting the recorded high-frequency current fluctuations. Simultaneous temperature records are affected as well because of changes in mooring inclination, particularly in the presence of large vertical temperature gradients. In spite of 
Table 1. Institut für Meereskunde (IfM) Kiel current meter moorings in the Cape Verde Frontal Zone

\begin{tabular}{|c|c|c|c|c|c|c|c|c|}
\hline \multirow{2}{*}{$\begin{array}{l}\text { If } \\
\text { code }\end{array}$} & \multirow{2}{*}{$\begin{array}{l}\text { IfM } \\
\text { ref. no. }\end{array}$} & \multicolumn{2}{|c|}{ Position } & \multirow{2}{*}{$\begin{array}{l}\text { Launch } \\
\text { ship }\end{array}$} & \multirow[b]{2}{*}{ Recording time } & \multirow{2}{*}{$\begin{array}{c}\text { Recovery } \\
\text { ship }\end{array}$} & \multirow{2}{*}{$\begin{array}{c}\text { No. of } \\
\text { instruments }\end{array}$} & \multirow{2}{*}{$\begin{array}{l}\text { Data } \\
\text { reports }\end{array}$} \\
\hline & & Longitude & Latitude & & & & & \\
\hline v & $307-1$ & $22^{\circ} 56.7^{\prime} \mathrm{N}$ & $20^{\circ} 30.7^{\prime} \mathrm{W}$ & $\mathbf{P}$ & $\begin{array}{l}8 \text { Oct. } 1985- \\
7 \text { Nov. } 1986\end{array}$ & $\mathbf{M}$ & $5 \mathrm{CM}$ & S86, S87 \\
\hline $\mathbf{Q}$ & $308-1^{*}$ & $21^{\circ} 59.0^{\prime} \mathrm{N}$ & $22^{\circ} 02.4^{\prime} \mathrm{W}$ & $\mathbf{P}$ & $\begin{array}{l}9 \text { Oct. } 1985- \\
9 \text { Nov. } 1986\end{array}$ & $M$ & $5 \mathrm{CM}+$ & $586, \$ 87$ \\
\hline \multirow[t]{2}{*}{$\mathrm{w}_{2}$} & $309.1^{*}$ & $19^{\circ} 02.4^{\prime} \mathrm{N}$ & $22^{\circ} 00.1^{\prime} \mathrm{W}$ & $\mathbf{P}$ & $\begin{array}{l}11 \text { Oct. } 1985- \\
14 \text { Nov. } 1986\end{array}$ & $M$ & $5 \mathrm{CM}+$ & S86, S87 \\
\hline & $309-2^{*}$ & $19^{\circ} 02.2^{\prime} \mathrm{N}$ & $21^{\circ} 59.3^{\prime} \mathrm{W}$ & $\mathbf{M}$ & $\begin{array}{l}15 \text { Nov. } 1986- \\
20 \text { Nov. } 1987\end{array}$ & $M$ & $5 \mathrm{CM}^{4}$ & S87, M88 \\
\hline W3 & $313-1^{*}$ & $20^{\circ} 29.6^{\prime} \mathrm{N}$ & $23^{\circ} 35.6^{\prime} \mathrm{W}$ & $M$ & $\begin{array}{l}13 \text { Nov. } 1986- \\
19 \text { Nov. } 1987\end{array}$ & $M$ & $5 \mathrm{CM}^{+}$ & $587, M 88$ \\
\hline W4 & $314-1$ & $21^{\circ} 55.8^{\prime} \mathrm{N}$ & $25^{\circ} 14.2^{\prime} \mathrm{W}$ & $\mathbf{M}$ & $\begin{array}{l}17 \text { Nov. } 1986 \\
18 \text { Nov. } 1987\end{array}$ & $M$ & $5 \mathrm{CM} / 2 \mathrm{ST}$ & S87. M88 \\
\hline
\end{tabular}

P, F.S. Polarstern; M, F.S. Meteor: CM, current meter; ST sediment trap. S86, Siedler (1986a); S87 Siedter et al. (1987); M88, Mititer al al. (1988).

* Mooring was damaged by fish bite. for details see dala report.

fInitial number of instruments.

the given deficiencies we feel that the low-frequency signals in the obtaincd current and temperature records are adequate for making rough estimations of preferred periods and spatial scales of variability in the main thermocline of the Cape Verde Frontal Zone.

\section{WATER MASSES AND STRUCTURE OF THE CAPE VERDE FRONTAL ZONE}

The frontal zone north of the CWB has been the focus of carlier investigations in this region, primarily in context with upwelling studies (cf. references in Table 2). A composite of CWB positions from the indicated synoptic surveys (Fig. 2) suggests there are spatial variations of the front at least of the order of $300 \mathrm{~km}$ in the region off Cape Blanc. As a definition of the CWB position, we adopt a well-proven criterion, the location of the 36.0 psu isohaline at $150-\mathrm{m}$ depth. Recently BARToN (1987) used the same and observed a northward penetration of SACW along the continental slope as far as $22^{\circ} \mathrm{N}$. He stressed the appearance of strong interleaving as an integral part of the frontal dynamics.

Water masses in the Cape Verde Frontal Zone can be best identified by potential temperature-salinity $(\theta-S)$ relations from hydrographic profiles. In Fig. 3 we display $(\theta-S)$ relations from all $67 \mathrm{CTD}^{-\mathrm{O}_{2}}$ stations obtained in November 1986 (cf. Fig. 1). We further include definitions of the two central water masses NACW and SACW according to Tomczak (1981).

Both central water masses appear in the permanent pycnocline between depths of 150 $600 \mathrm{~m}$ at temperatures greater than about $10^{\circ} \mathrm{C}$. They are characterized by a tight, almost linear, $\theta-S$ relationship. In Table 2 we review historical definitions of $\theta-S$ end points for NACW and SACW. In some cases, the historical definitions also include nutrient and oxygen concentrations. Due to regional differences, some values are inconsistent with each other. As is evident in Table 2, both water masses NACW and SACW show 


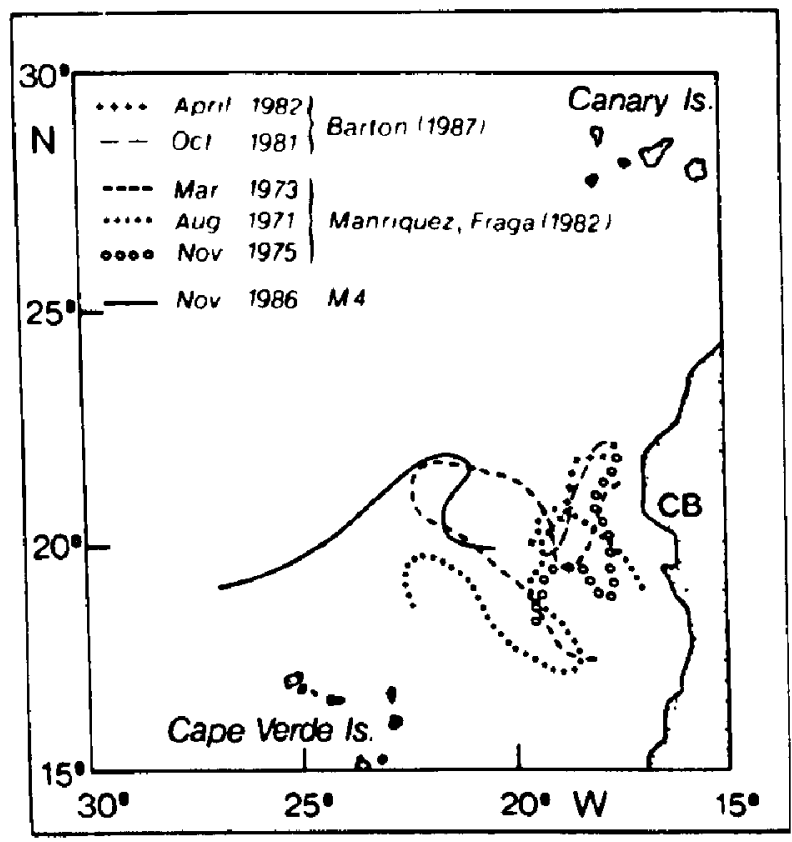

Fig. 2. Historical quasi-synoptic positions of the Central Water Boundary (CWB) west of Cape Blanc (CB).

significant regional deviations from the global definitions introduced by Sverdrup et al. (1942).

The typical S-shaped pattern of the $\theta-\mathrm{S}$ relations below $8^{\circ} \mathrm{C}$ at a depth range of $800-1600$ $\mathrm{m}$ (Fig. 3), is caused by two other distinct water masses being present. First is the AAIW, which derives from a mixture of Antarctic and subantarctic surface waters (PIOLA and GeORGI, 1982). This water mass is relatively fresh and rich in nutrients. Second is the warm, saline and nutrient-poor MW, which enters the North Atlantic through the Strait of Gibraltar and spreads in the depth range of $800-1200 \mathrm{~m}$.

The layers below $1200 \mathrm{~m}$ and colder than $4^{\circ} \mathrm{C}$ are dominated by the NADW, which originates in the northern North Atlantic and is characterized by high oxygen and low nutrient values. In contrast to the upper layer, where SACW/NACW and AAIW/MW fronts are found, no discontinuity is detectable in the deep waters of the Cape Verde Frontal Zone.

In Fig. 4 the boundary between the central waters NACW (left) and SACW is seen in the upper $600 \mathrm{dbar}$ by the strong thermohaline fronts between station pairs 304/303 and 302/ 301. Due to a frontal meander or an isolated eddy restricted to the upper $500 \mathrm{dbar}$, Sta. 301 shows NACW characteristics. At the 150 dbar level on each side of the SACW core (303 and 302), our section resolves a temperature change of $>3{ }^{\circ} \mathrm{C} / 40 \mathrm{~km}$ and an associated salinity change of $>0.8 \mathrm{psu}$. The corresponding density gradients are small, apparently because a large amount of the T-S fine structure is density-compensating. It is worth noting that the CWB is barely detectable in the upper $50 \mathrm{~m}$. This is in contrast to the upwelling regions further east where the CWB extends almost vertically to the surface (MANRIQUez and Fraga, 1982; Barton, 1987).

At pressures $>600 \mathrm{dbar}$, another pronounced discontinuity exists in the salinity field (Fig. 4). The 35.0 psu contour describes a marked S-shaped structure. This feature is caused by the meeting of highly saline MW (left) with the fresher AAIW. This mid-depth 
front is also reflected in numerous smaller-scale inversions in the original CTD- $\mathrm{O}_{2}$ traces (not shown). The underlying NADW, below 2000 dbar in section A, displays little significant contrast in the horizontal.

The most prominent feature for dissolved oxygen and nutrients along $A$ in the upper layers is the upward doming of isolines due to the nutrient-rich, poorly oxygenated SACW (Fig. 5). Oxygen values of $<1.5 \mathrm{ml} \mathrm{l}^{-1}$ are observed in the SACW. As will also be seen along section $B$, there is a significant density difference between where the oxygen minimum and the intermediate phosphate and nitrate maxima are found. While the isolated oxygen minimum appears to be a tracer for the penetration of SACW, we interpret the nutrient maxima and deeper low oxygen tongue as clear indicators of AAIW with the underlying high silicate values ( $>30 \mu \mathrm{mol} \mathrm{dm}^{-3}$ ) as belonging to NADW.

Vertical distributions of temperature, salinity and density southwest of the parallel section A (Fig. 6, section B) show a sandwich-like distribution of water masses. In the northwest, we recognize the typical subtropical Salinity Maximum Water of the North Atlantic. This water mass is formed in the inner subtropical gyre where evaporation exceeds precipitation, and has recently been studied by BAUER and StEDLER (1988).

Above 600 dbar, the CWB is situated hetween Stas 318 and 319 with NACW on its northern (left) side and SACW on its southern. Contrasts in temperature and salinity

Table 2. Linear definitions for North Allantic Central Water (NACW) and South Allantic Central Water $(S A C W)$ as collected from the literature. Temperature in ${ }^{\circ} \mathrm{C}$, salinity in psu, sigma in $\mathrm{kg} \mathrm{m}^{-1}$ and nutrients in $\mu \mathrm{mol}$ dm ${ }^{3}$

\begin{tabular}{|c|c|c|c|c|c|c|c|c|c|c|c|c|c|}
\hline & $T$ & $\mathbf{S}$ & $\sigma_{i}$ & $\mathrm{NO}_{1}$ & $\mathrm{PO}_{4}$ & $\mathrm{SiO}_{4}$ & & $\mathrm{~T}$ & S & $a_{1}$ & $\mathrm{NO}_{3}$ & $\mathrm{PO}_{4}$ & $\mathrm{SiO}_{4}$ \\
\hline \multicolumn{7}{|c|}{ Upper end NACW } & \multicolumn{7}{|c|}{ Upper end SACW } \\
\hline MF & 18.00 & 36.38 & 26.33 & & & & MF & $18 .(x)$ & 35.90 & 25.96 & & & \\
\hline FBLI & 18.00 & 36.57 & 26.48 & 8.27 & 0.41 & 2.27 & FBL1 & 17.801 & 35.78 & 25.92 & 23.10 & .55 & 0.00 \\
\hline $\mathrm{T}$ & 18.65 & 36.76 & 26.46 & 2.10 & 0.00 & 0.001 & $\mathrm{~T}$ & 15.25 & 35.70 & 26.46 & 22.20 & 1.50 & 9.00 \\
\hline FBL2 & 18.65 & 36.76 & 26.46 & 3.91 & 0.11 & 0.35 & FBL2 & 15.25 & 35.70 & $2 h .46$ & 25.801 & 1.59 & 6.13 \\
\hline SFJ & 19.00 & 36.70 & 26.32 & & & & SFJ & $\mid 8 .(x)$ & $36 .(0)$ & 26.04 & & & \\
\hline MDB & 18.65 & 36.52 & 26.27 & 0.00 & 0.001 & 0.001 & MDB & 15.25 & 35.70 & 26.46 & 22.511 & 1.50 & 8.00 \\
\hline EM & 18.00 & 36.70 & 26.58 & & & & $\mathbf{E M}$ & 18.00 & 35.80 & 25.89 & & & \\
\hline W & 17.50 & 36.40 & 26.47 & & & & w & $\ln .0(1)$ & 35.65 & 26.25 & & & \\
\hline \multicolumn{7}{|c|}{ Lower end NACW } & \multicolumn{7}{|c|}{ Lower end SACW } \\
\hline MF & 10.00 & 35.35 & 27.23 & & & & MF & $10 .(x)$ & 34.86 & 26.84 & & & \\
\hline FBLI & 6.50 & 34.90 & 27.41 & 33.42 & 1.88 & 16.37 & FBLI & 5.50 & 34.65 & 27.34 & 46.59 & 2.66 & 26.20 \\
\hline $\mathrm{T}$ & 11.00 & 35.47 & 27.14 & 18.00 & 1.19 & 5.00 & $T$ & 9.70 & 35.18 & 27.14 & 33.00 & 2.30 & 21.00 \\
\hline FBL2 & 11.00 & 35.47 & 27.14 & 27.20 & 1.52 & 13.94 & FBL2 & 9.70 & 35.18 & 27.14 & 33.10 & 1.92 & 16.25 \\
\hline SFJ & 8.00 & 35.10 & 27.35 & & & & SFJ & 6. $(x)$ & 34.50 & 27.16 & & & \\
\hline MDB & 9.90 & 35.47 & 27.34 & 20.70 & 1.38 & 5.80 & $M D B$ & 9.70 & 35.18 & 27.14 & 34.50 & 2.30 & 17.00 \\
\hline EM & 8.00 & 35.20 & 27.43 & & & & EM & 5.00 & 34.30 & 27.12 & & & \\
\hline w & 8.00 & 35.20 & 27.43 & & & & w & 8.00 & 34.70 & 27.04 & & & \\
\hline
\end{tabular}

MF, Manriquez and Fraga (1982).

FBL1/2, Fraga et al. (1982) (2 versions).

T, TOMCzak (1981).

SJF, SVERdrup et al. (1942).

MDB, Mackas et al. (1987).

EM, EMERY and MeINCKe (1986).

W, WiLlenbrink (1982). 


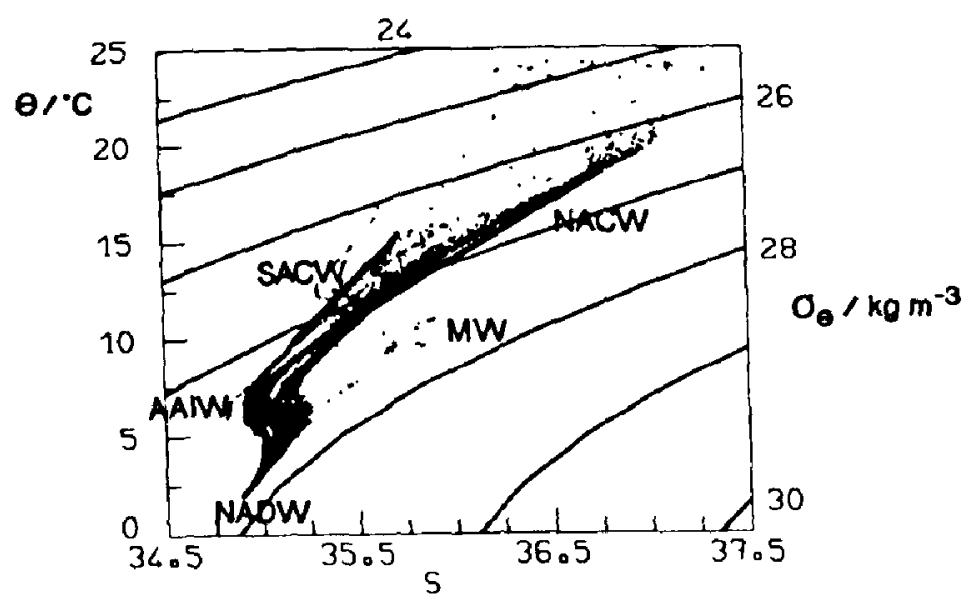

Fig. 3. Composite potential temperature-salinity diagram for all 67 hydrographic stations occupied by Meteor in November 1986 together with acronyms of water masses found in the region. Heavy bars denote the definitions for South and North Atlantic Central Water (SACW/NACW) given by TOMCZAK (1981). AAIW, MW and NADW stand for Antarctic Intermediate, Mediterranean and North Atlantic Deep Water.
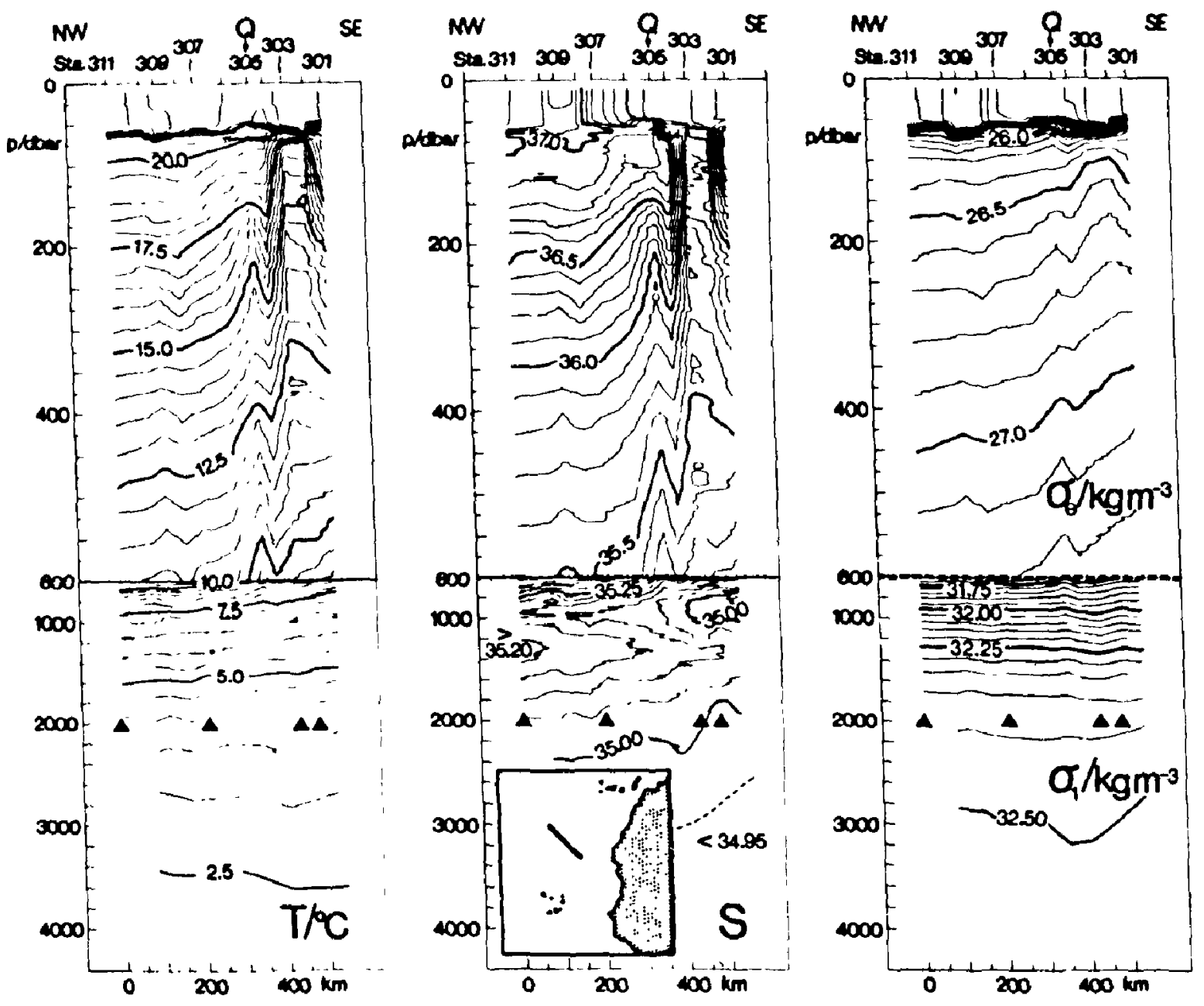

Fig. 4. Vertical distributions of temperature, salinity and density (sigma-theta/sigma 1) along section $A$. Below 600 dbar the vertical scale has been changed. Triangles indicate maximal pressure of individual CTD $-\mathrm{O}_{2}$ stations. For better resolution isohaline intervals change at $600 \mathrm{dbar}, \mathrm{Q}$ depicts position of mooring $Q$ situated close to the Central Water Boundary. 

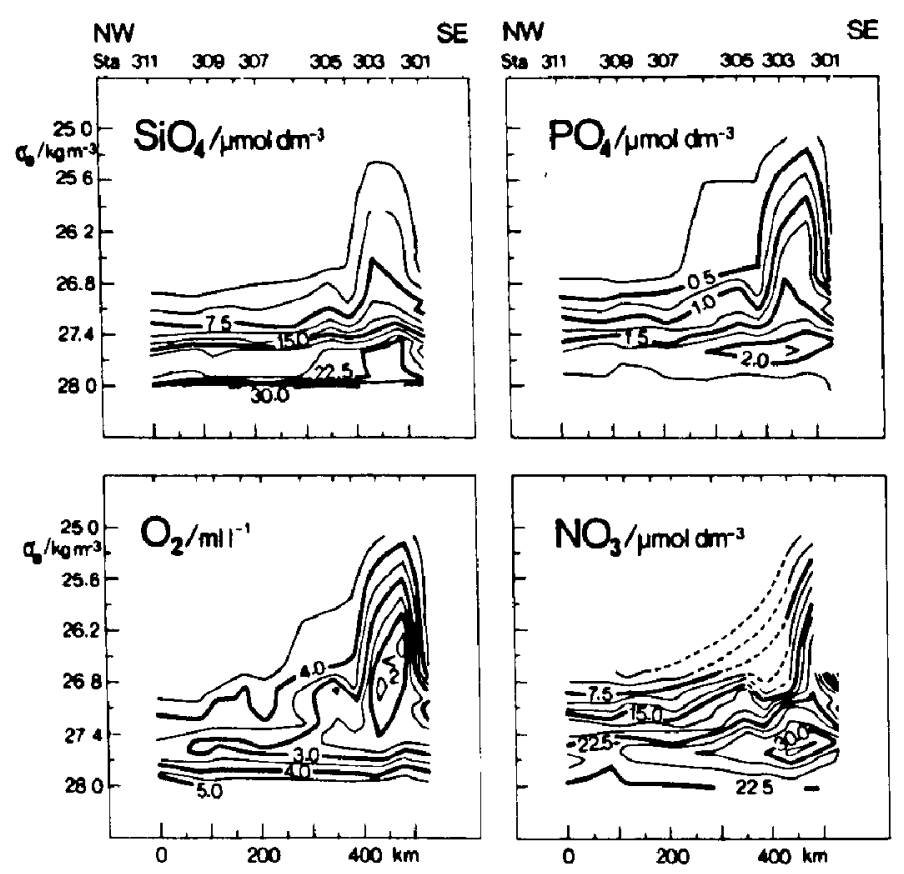

Fig. 5. Vertical distributions of nutrients and dissolved oxygen along section $A$ in density coordinates (sigma-theta). Intermediate extrema identify characteristic water masses (for details see text.)

across the CWB are weaker than along section $\mathrm{A}$, here reaching $3.5^{\circ} \mathrm{C}$ and 0.9 psu over a distance of $100 \mathrm{~km}$ at $150 \mathrm{dbar}$. The characteristic $36.0 \mathrm{psu}$ isoline is lifted from $350 \mathrm{dbar}$ on the northern side to nearly $120 \mathrm{dbar}$ in the south. The associated density section shows relatively weak gradients at $150 \mathrm{dbar}$, which reflects the density compensating character of the Cape Verde Frontal Zone.

A pronounced upward doming of isolines in the upper layers is visible at Sta. 315. This intrusion is situated over a high-salinity feature at the $1200 \mathrm{dbar}$ level, which we will return to in Section 5. As seen along the line of stations in A, we can trace the CWB down to the tops of the MW and AAIW layers. Again we recognize the characteristic S-shaped curve at 800-1400 dbar of the 35.0 psu isohaline separating these intermediate water masses.

Distributions of oxygen and nutrients along section B are depicted in density coordinates in Fig. 7. Unfortunately no bottle data are available from Sta. 319. The main gradients appear south of Sta. 318 where Meteor entered the SACW region. Distributions of vertical extrema are similar to those along section $A$, with the low oxygen tongue being less structured. Both the shallower SACW oxygen minimum, which is bounded by the CWB, and the deeper main minimum are reproduced in Fig. 7. The latter indicates the northernmost extension of AAIW at approximately $24^{\circ} \mathrm{N}$ (Sta. 313).

Quasi-synoptic horizontal distributions of various properties in the Cape Verde Frontal Zone and adjacent regions were analysed objectively (HILlER and KäsE, 1983). Prior to this analysis spatial trends were removed. Error variance is assumed to be $15 \%$ of the total variance. In the stippled regions the error variance exceeds $50 \%$ of the total variance. The results are shown in Figs 8 and 9. The large distance between individual sections forced us to use a correlation length scale of $300 \mathrm{~km}$, resulting in strongly reduced horizontal property gradients. Our analysis is carried out on two density levels in order to display upper-ocean water mass distributions. The CWB is clearly seen on the $\sigma_{t}=26.7$ surface 
H
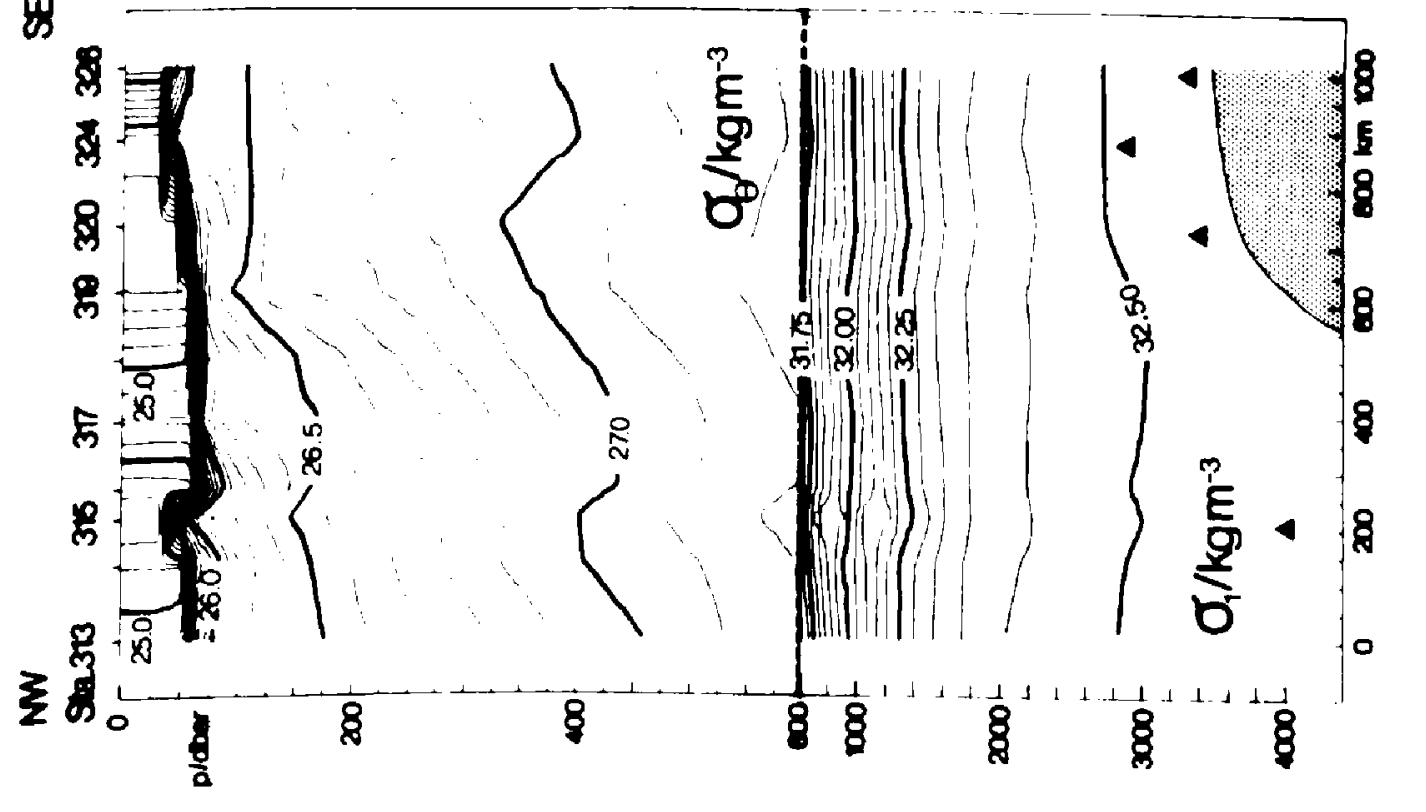

$y$
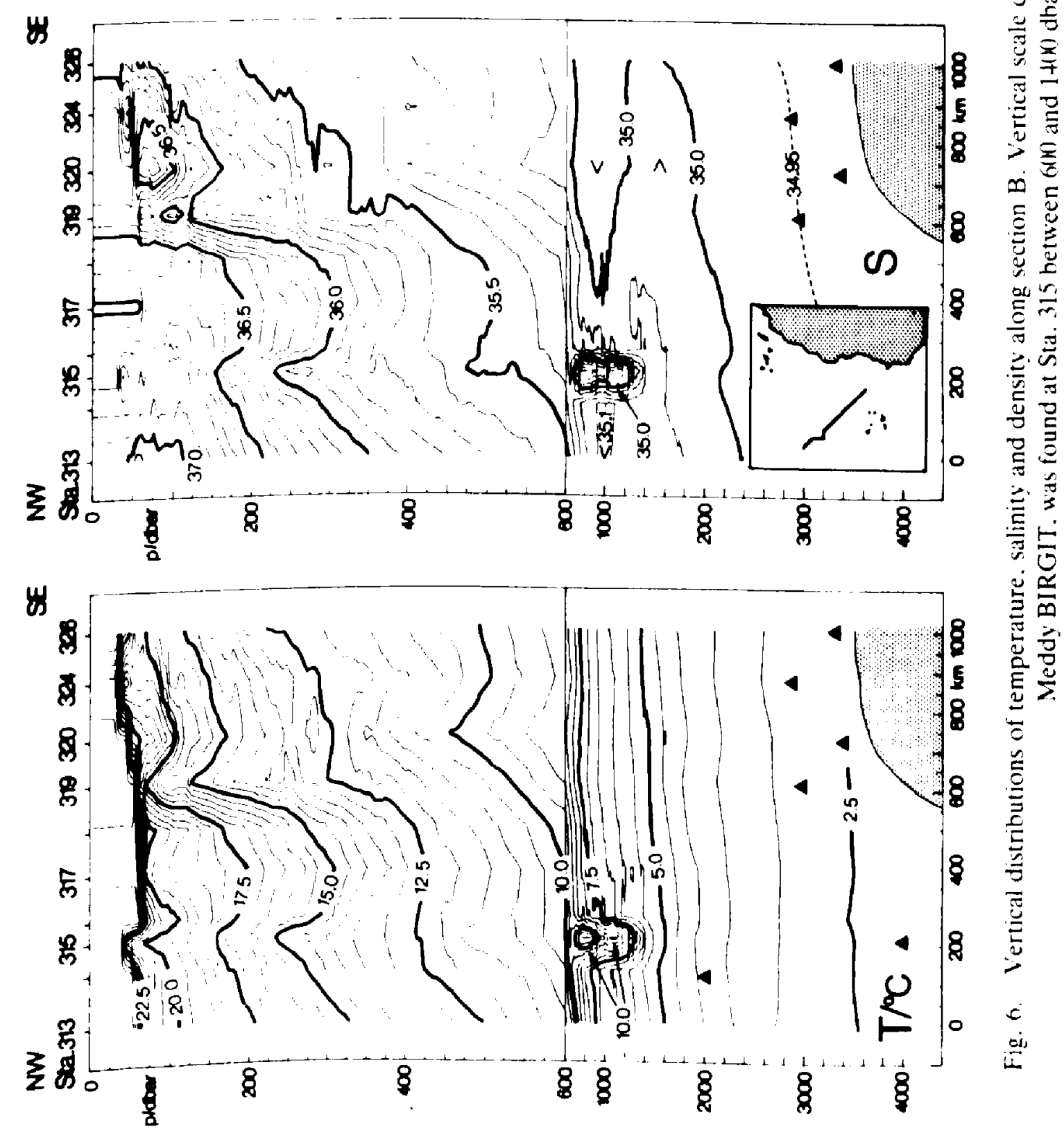

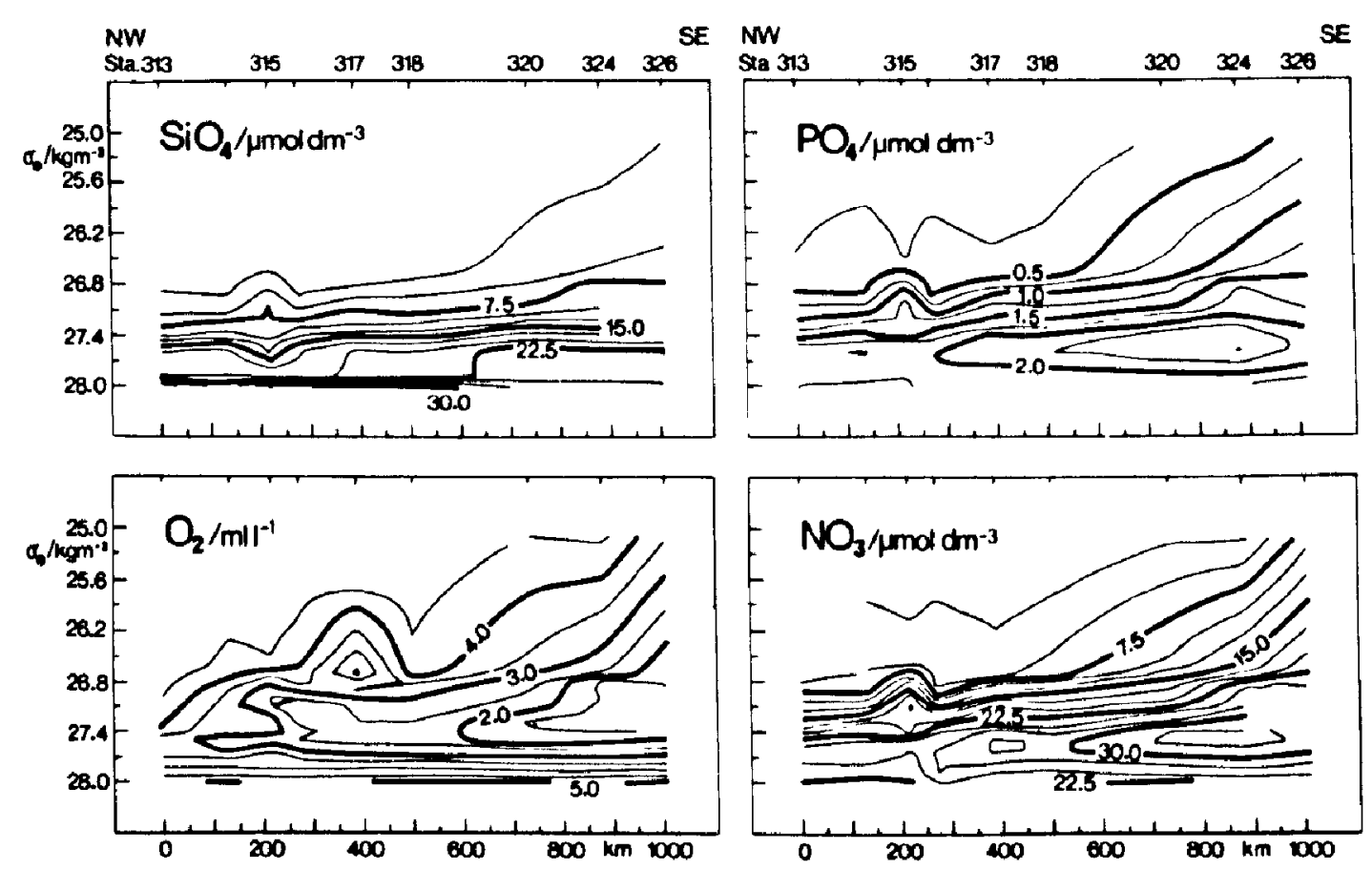

Fig. 7. Distributions of nutrients and dissolved oxygen along section B in density coordinates (sigma-theta). As seen in Fig. 5 , intermediate extrema identify characteristic water masses.

(approx. $250 \mathrm{dbar}$ ), whereas the vertical boundary between AAIW and MW is clear on the $\sigma_{t}=27.4$ (approx. $900 \mathrm{dbar}$ ) surface.

On the $\sigma_{t}=26.7$ surface (Fig. 8), temperature, salinity and oxygen all show a general increase across the CWB towards the northwest corner, whereas the nutrient concentrations are characterized by increasing values towards the shadow zone in the southeast corner, west of Cape Verde (Senegal). Our observations agree with the concept that freshly ventilated thermocline waters in the North Atlantic subtropical gyre do not cross the CWB (Siedler, 1986b). The northward flux of highly nutrified SACW across the equator along the African shelf is confirmed by the wedge-like distributions of $\mathrm{SiO}_{4}, \mathrm{PO}_{4}$ and $\mathrm{NO}_{3}$ concentrations. As expected, $\mathrm{PO}_{4}$ and $\mathrm{NO}_{3}$ show a high degree of horizontal correlation. There is a region of weak gradients in all parameters along the west side between $18^{\circ}$ and $21^{\circ} \mathrm{N}$, hence indicating strong variability in the Cape Verde Frontal Zone and enhanced horizontal mixing. The vigorously ventilated region apparently is restricted to the northern rim of the CWB. Theoretical studies (ONKEN and KLEIN, 1990) have shown this area to be baroclinically unstable.

On the deeper surface of $\sigma_{t}=27.4$ (in Fig. 9) we find quite a different picture concerning the AAIW/MW front. This meandering front, strongly smoothed by the objective analysis, is confined largely to the northern area (north of $20^{\circ} \mathrm{N}$ ). In the west, AAIW is found farther north as compared with the shallower SACW. Apparently the northward drift of AAIW is arrested by the warmer and more saline MW north of $22^{\circ} \mathrm{N}$. The westward divergence of the dual frontal system SACW/NACW and AAIW/MW has been clearly seen and described in the meridional section along $27.0^{\circ} \mathrm{W}$ (SIEDLER et al., 1987). Also previously described is the pronounced $\mathrm{SiO}_{4}$ maximum off western Africa coincident with an oxygen minimum, which KaWASE and SARMIENTo (1986) explained as being due to strong oxygen consumption during regeneration of sinking organic material. 


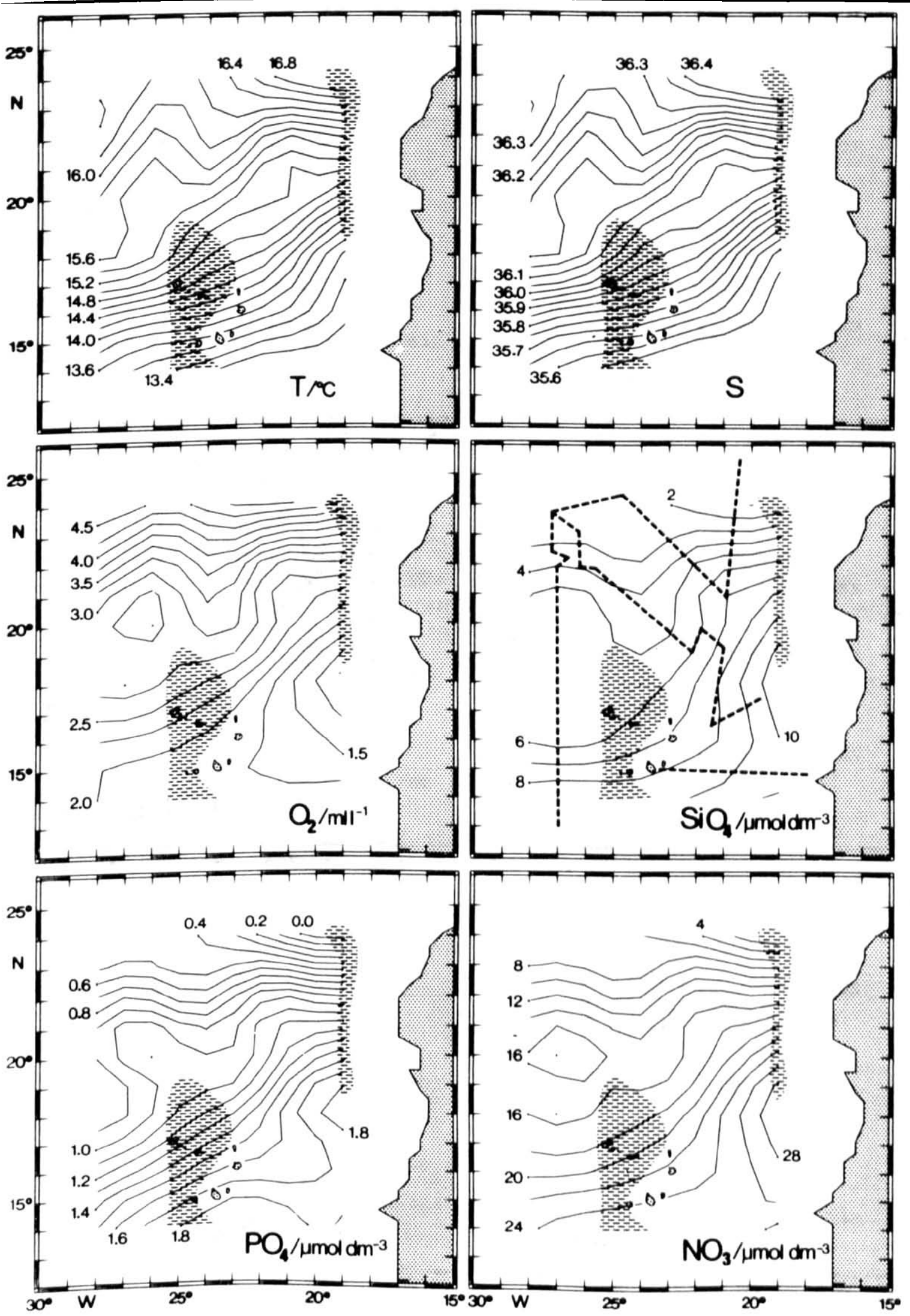

Fig. 8. Isopycnal distributions of temperature, salinity, nutrients and dissolved oxygen on the potential density surface of $\sigma_{t}=26.7$ (averaged depth $250 \mathrm{~m}$ ). Ship's track is indicated by broken lines. In the stippled area the error variance of the objective analysis exceeds $50 \%$ of the total variance. This density level is characteristic for the central waters separated by the Central Water 

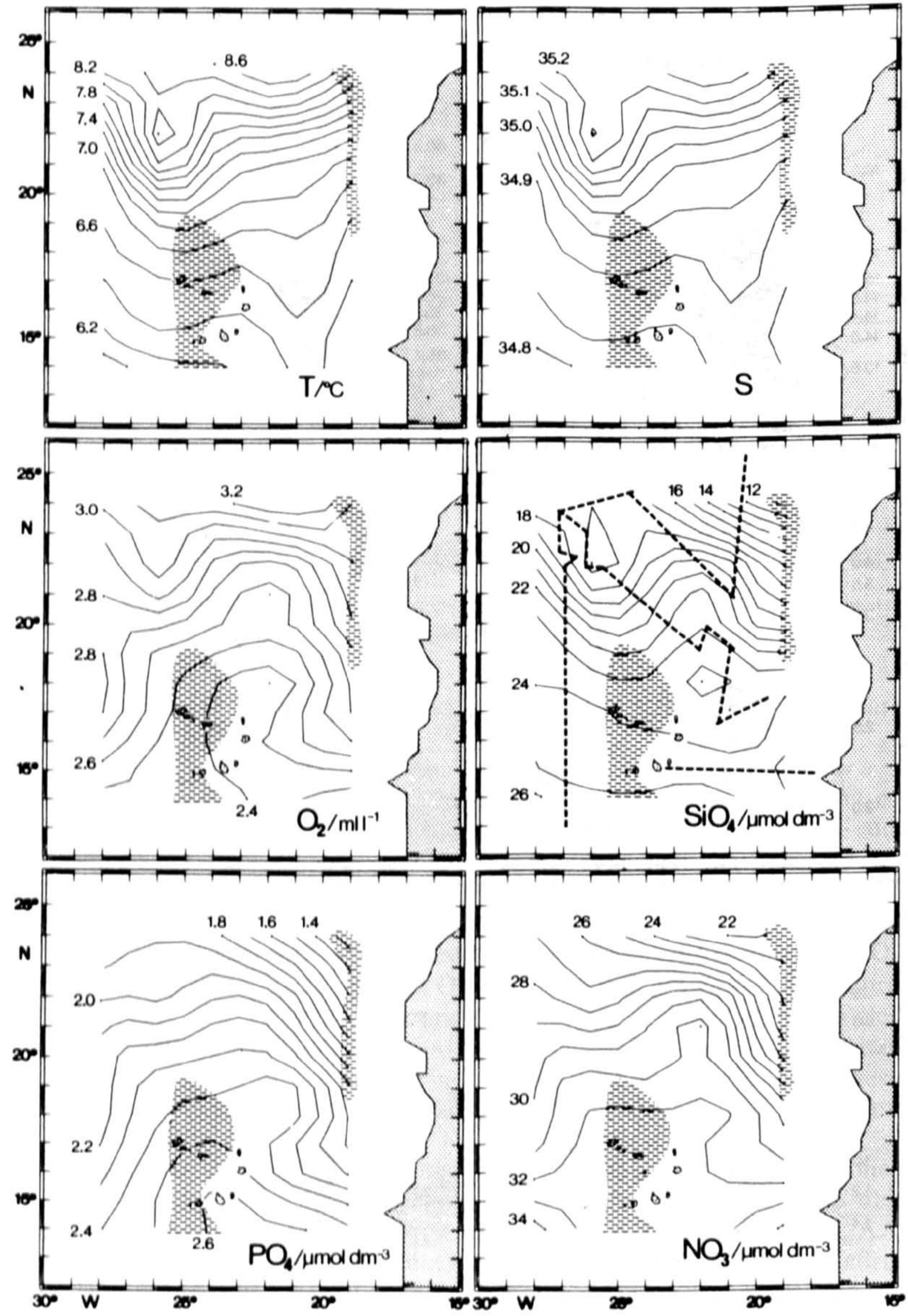

Fig. 9. Isopyenal property distribution on the potential density surface of $\sigma_{t}=27.4$ (averaged depth $Y(x) \mathrm{m})$. Mediterranean Wuter in the north is separated zonally from Antarctic Intermediate Water farther south. 


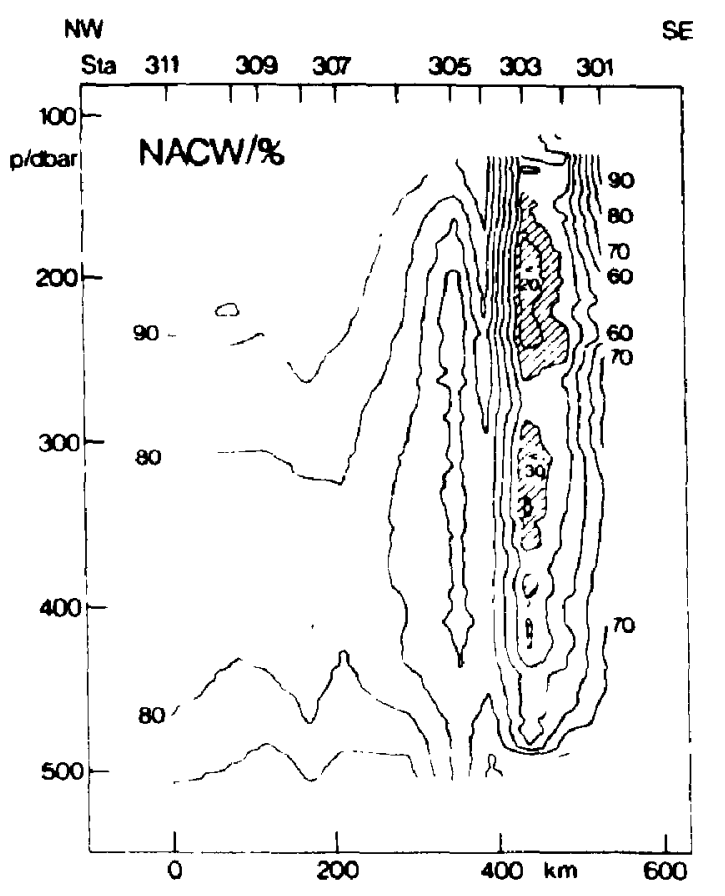

Fig. 10. Analysis of isopycnal mixing of the two thermocline water masses along section A. Percentages of North Atlantic Central Water are shown here. The envolved South Atlantic Central Water may be calculated by SACW $\%=100-\mathrm{NACW} \%$.

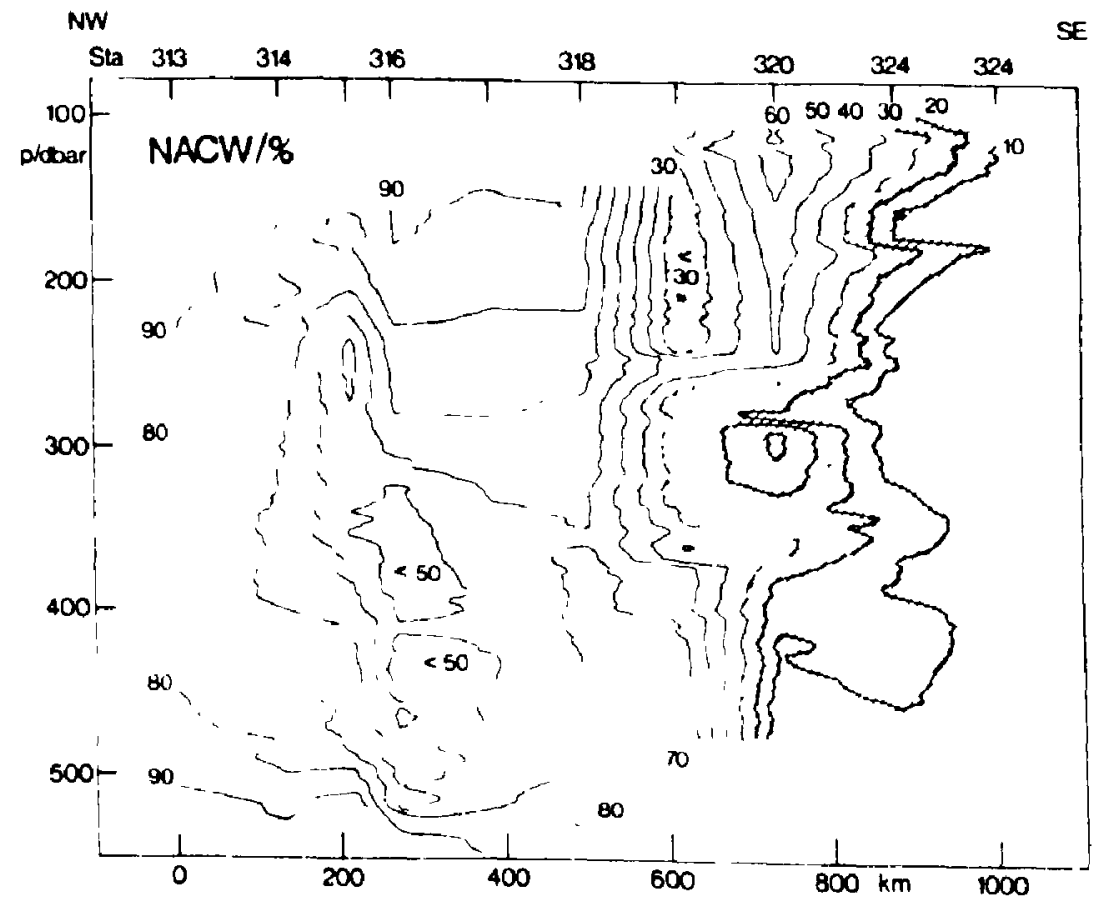

Fig. 11. Isopycnal mixing analysis along section B. Areas with less than $30 \% \mathrm{NACW}(\geq 70 \%$ $S A C W$ ) are hatched. 
Assuming that mixing takes place mainly on isopycnals, we calculate the percentage of SACW and NACW in the thermocline along sections $A$ and $B$ between the potential density surfaces of $o_{\theta}=26.46$ and 27.14 . These density levels are adopted from TomczAK's (1981) definition for the vertical distribution of NACW and SACW (Table 2 and Fig. 3). The relative amounts of NACW and SACW in the mixture are given by the distances between the 'T-S curves of the "pure" water masses and the observed T-S point, measured along the isopyenal through this point. Our mixing analysis (Figs 10 and 11) shows the large reservoir of NACW towards the northwest. The core of high SACW concentration $(>70 \%)$, i.c. low NACW concentration $(<30 \%)$, in the southeast is indicated by hatching. Figure 10 reveals the convoluted structure of the $C W B$ along section $A$. with a meander of the order of $1(0) \mathrm{km}$ width at the southeastern end. We further note that no tilt of the CWB is resolved along section $A$.

The distributions of these water masses are more complex in section B (Fig. 11). The CWB is identified here between Stas 318 and 319 , apparently with a slight upward inclination toward the northwest. Intrusions of NACW and SACW are observed on both sides of the (WB, which are likely due to cross-frontal mixing. Strong mixing is evident at Stas 315 and 316 , where nearly equal contributions from each water mass are found. The question of how this enhanced local mixing is related to the deep intrathermocline eddy (cf. Fig. 6 at $12(x)$ dhar) is unanswerable. We will return to this in Section 5.

\section{GEOSTROPHIC CURRENTS AND TRANSPORTS}

Two different data sets. hydrographic data and current meter records, are used to illustratce the velocity structure in the (ape Verde Frontal Zone. Dynamic topography of

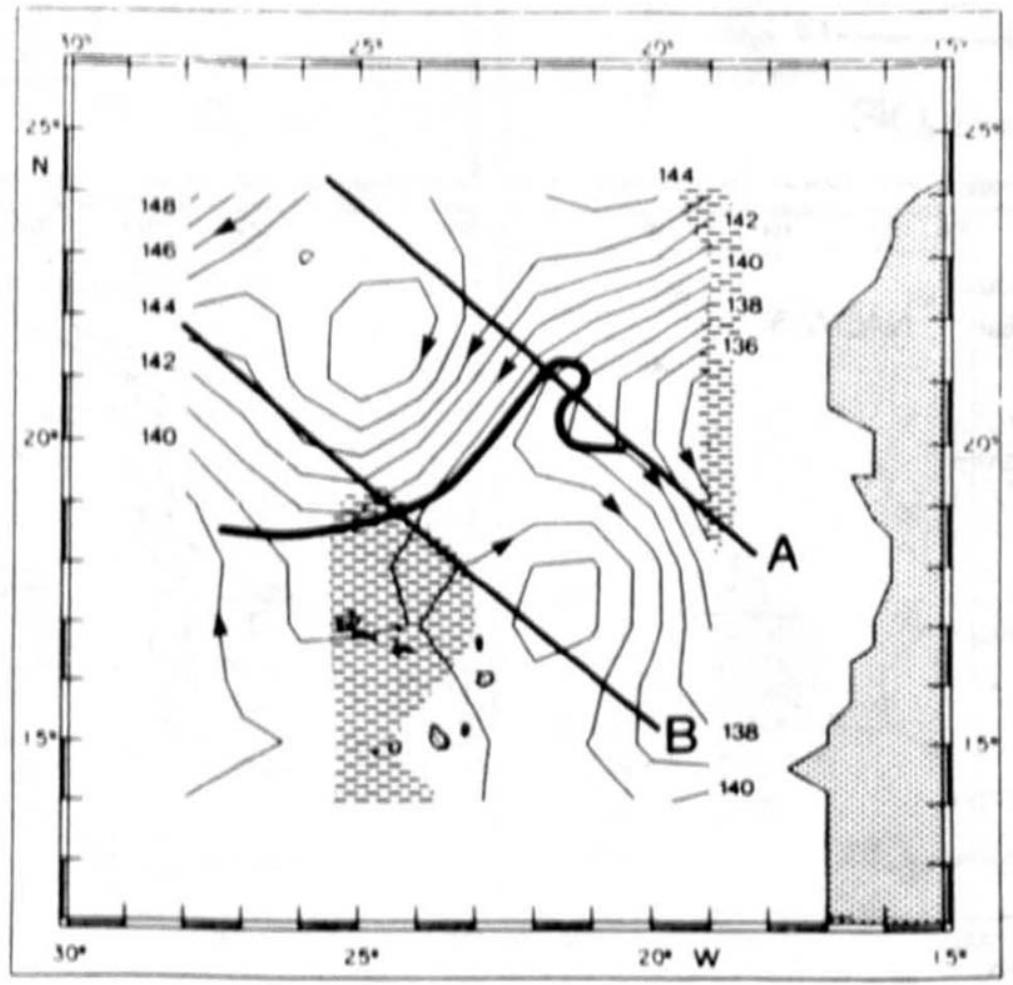

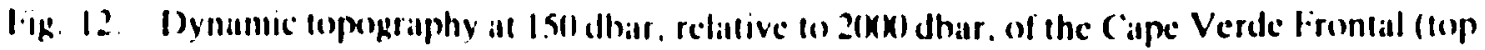
lefl) and the Shadew Zone (lower right corner). Isoline interval is $11.1 \mathrm{~J} \mathrm{~kg} \mathrm{'.} \mathrm{In} \mathrm{the} \mathrm{stippled} \mathrm{areal}$ the errer vatunnece excecels $50 \%$ " of the totul variance. The heavy line indicates the central Water Besundary an inlerred from the position of the 36.11 psu isohaline at 1501 dhar. This is also shown in Fig. 2 
the $150 \mathrm{dbar}$ level relative to $2000 \mathrm{dbar}$, a reference layer in a region of minimal motion below the AAIW/MW front (Fig. 12), is dominated by the Canary Current, which is north of the CWB, and becomes the North Equatorial Current between $20^{\circ}$ and $24^{\circ} \mathrm{N}$. Our quasisynoptic picture from November 1986 agrees well with the climatological mean position inferred from historical data by STRAMma (1984).

Geostrophic flow distribution and inferred cumulative volume transports along $\mathrm{A}$ are rather complex, showing alternating northeastward and southwestward flowing current filaments. The volume transport of the main southwestward current bands (stippled areas in Fig. 13) are of the order of $6 \mathrm{~Sv}\left(1 \mathrm{~Sv}=10^{6} \mathrm{~m}^{3} \mathrm{~s}^{-1}\right)$ each. The total volume transport in the Cape Verde Frontal Zone across section $A$ is towards the southwest and amounts to 4.6 Sv (Fig. 14). It is worth noting that mooring site $Q$ at Sta. 305 was situated in a region of strong horizontal shear. Because of this, we expect strong direction changes associated with shifts of the CWB. As will be demonstrated later, such changes in front position are observed in the year-long current meter records.

Geostrophic currents across section B (Fig. 15) also show a banded structure. Regions of southwestward flow (stippled areas in Fig. 15) are separated by two northeastward jets, each of which has an intermediate velocity maximum. The eastern jet, as seen in Fig. 12, might be interpreted as an eastern boundary current as earlier described by MITTELSTAEDT (1983). The western branch, with its maximum speed near the $1000 \mathrm{~m}$ level, represents the strongly smoothed dynamical signal of a salt lens to be described later.

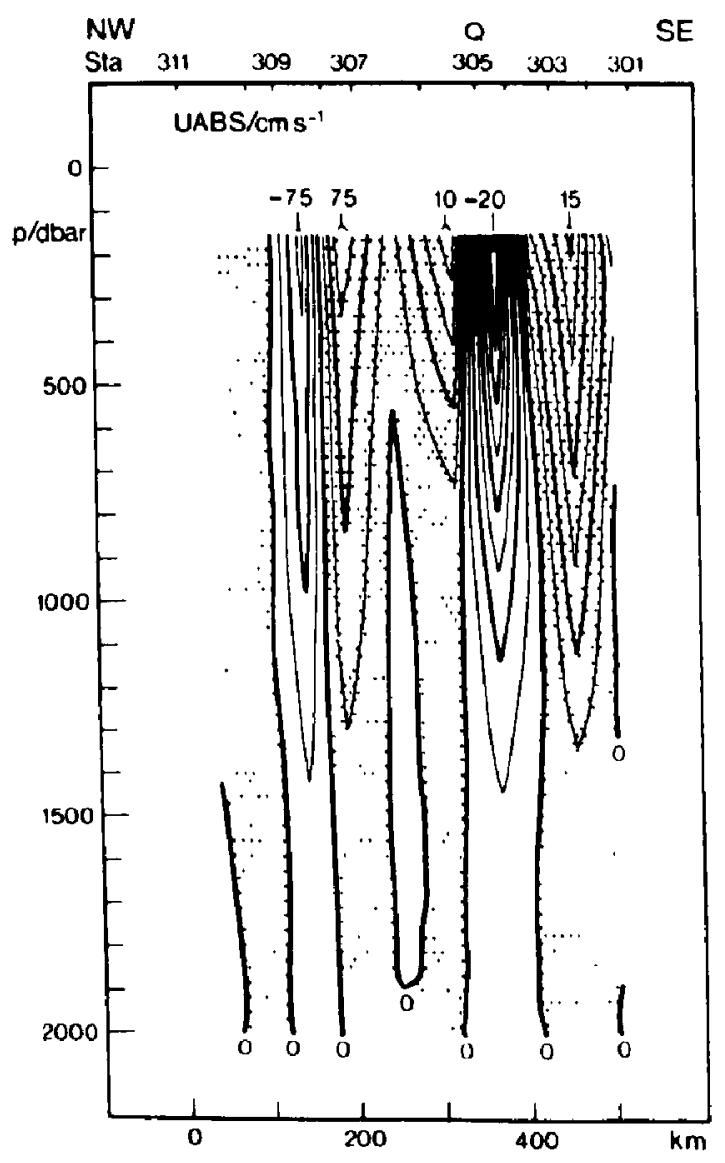

Fig. 13. Geostrophic current distribution relative to $2000 \mathrm{dbar}$ (zero velocity) across section $\mathbf{A}$. Isoline interval is $2.5 \mathrm{~cm} \mathrm{~s}^{-1}$. Areas of southwestward flow are dotted. Long-term current meter mooring $Q$ was situated in a region of strong horizontal current gradients. 


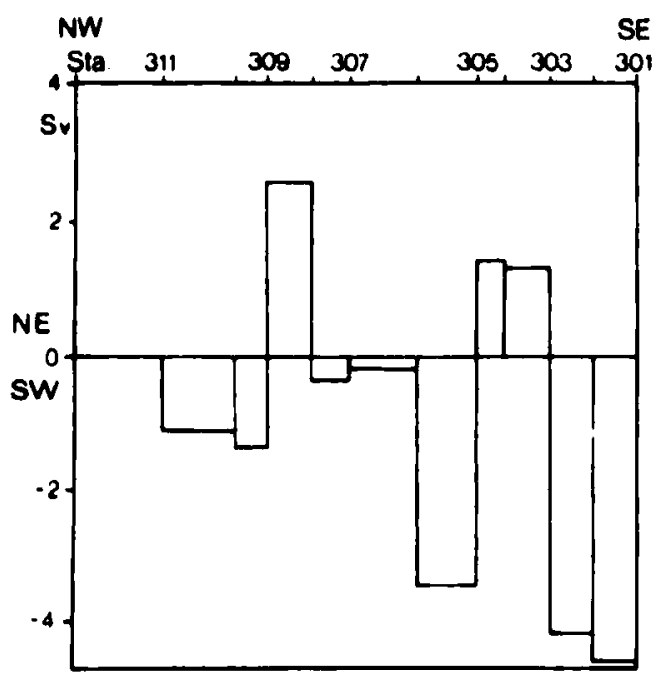

Fig. 14. Cumulative geostrophic transport along section A relative to $2000 \mathrm{dbar}$.

The southwestward volume transport of the Canary Current is largely confined between Stas 316 and 319 , where we observe upper thermocline velocities of $>8 \mathrm{~cm} \mathrm{~s}^{-1}$. The transport between Stas 317 and 319 amounts to $4.8 \mathrm{~Sv}$, whereas the transport integral (Fig. 16) across the Cape Verde Frontal Zone between Stas 315 and 319 yields a substantially higher value of $6.0 \mathrm{~Sv}$.

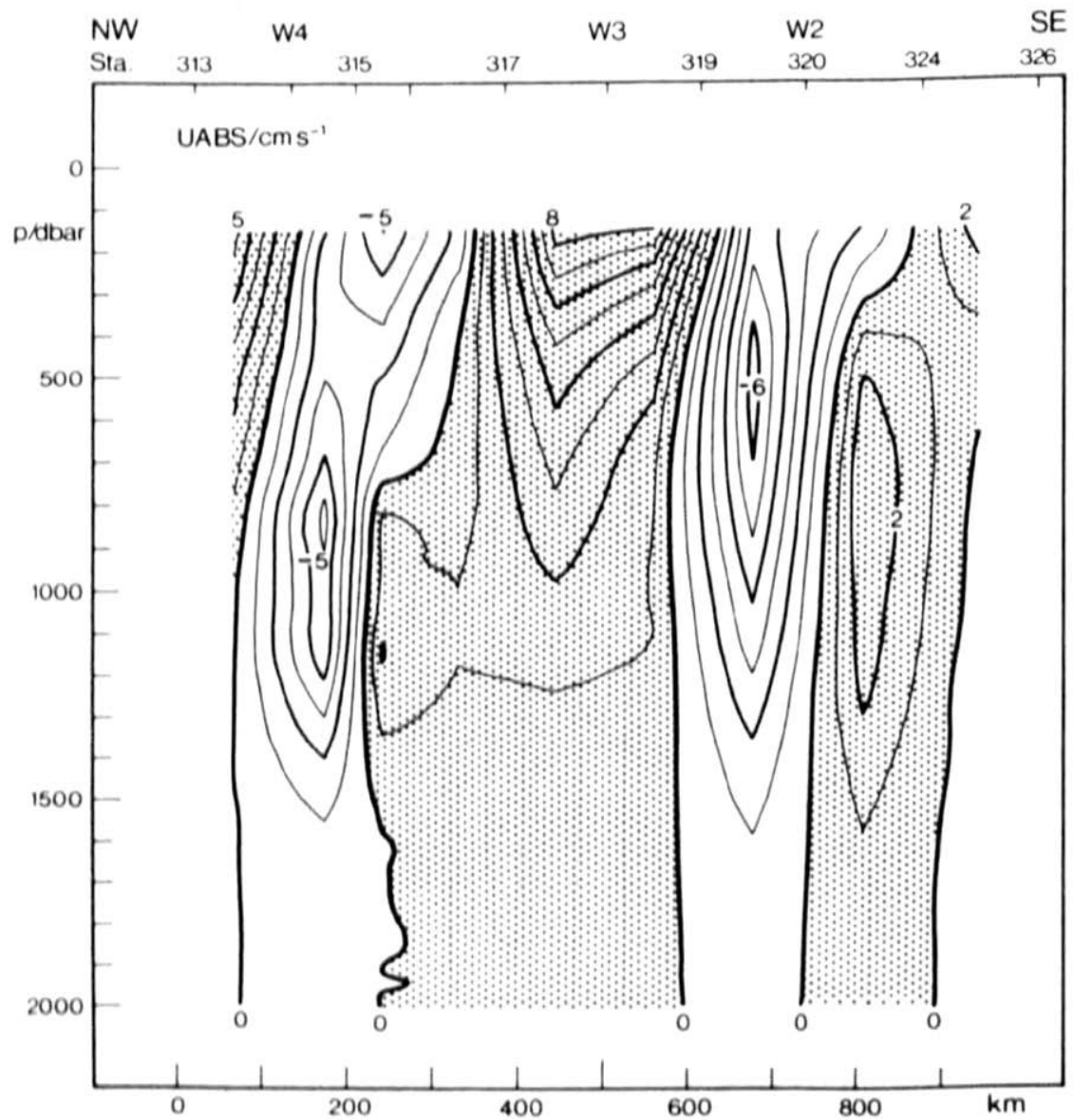

Fig. 15. Geostrophic current distribution across section B similar to Fig. 13. The southwestward Cunury Current is present between Stas 316 and 319 . The intrathermocline eddy at the 1000 dbar level is described in more detail in Fig. 20. 


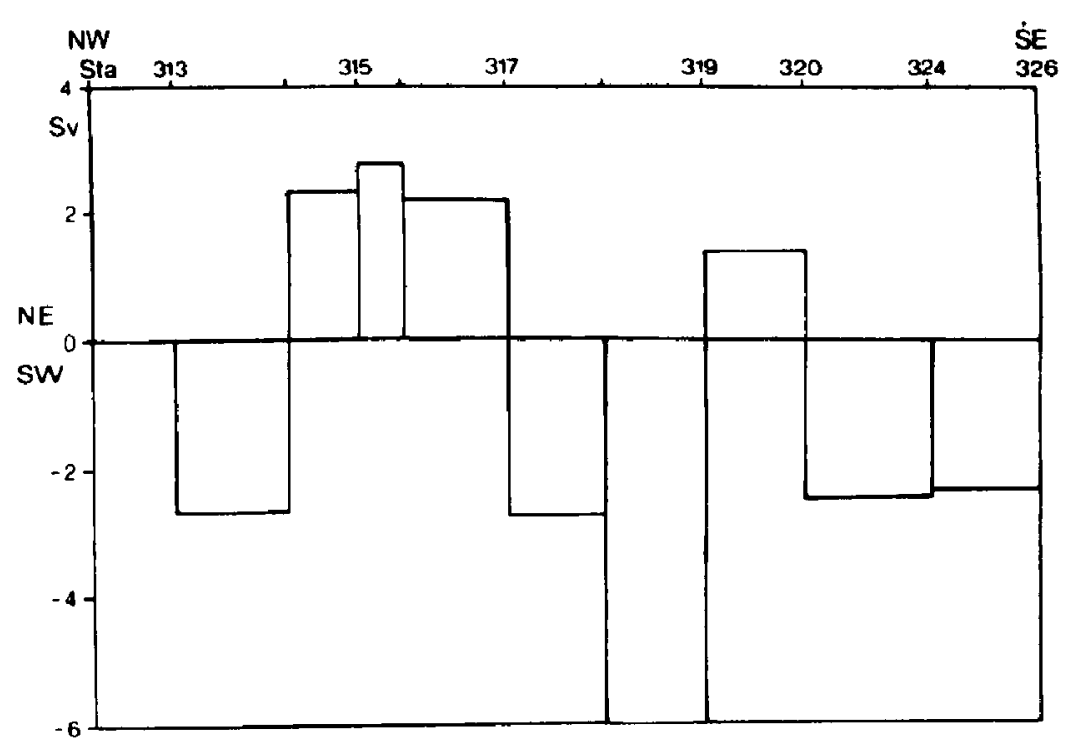

Fig. 16. Cumulative geostrophic transport along section B relative to $2000 \mathrm{dbar}$.

\section{DIRECT CURRENT MEASUREMENTS}

In this section we discuss current meter records which are potentially representative of current variations in both the NACW and SACW. Being aware of the technical problems with the moorings as previously described, we choose for display records from the most complete level, that being at a nominal depth of $400 \mathrm{~m}$, together with two adjacent isothermal plots inferred from the three uppermost Aanderaa current meters on V and W4 (Fig. 17). The complete data set was documented by SIEDLER $e t$ al. (1987) and MülLER $e t$ al. (1988). With the exception of the re-installed 2-year mooring W2, all other positions, V, Q, W3 and W4 (cf. insert in Fig. 17), were operational for only approximately 12 months. The temperature and velocity time series used here have been smoothed with a 2 day low-pass filter.

Most of the temperature fluctuations in the V and W4 moorings are highly correlated in the vertical. They often coincide with simultaneous strong current events measured by the same recorders (Fig. 17) as stick diagrams below (V) or above (W4) the temperature records. Due to buoyancy problems mentioned earlier, we must conclude that most of the short-period temperature changes reflect current fluctuations. Nevertheless, our temperature records should give some information about events occurring over longer period time scales. In both temperature records, $\mathrm{V}$ and $\mathrm{W} 4$, we count several significant cold events during the course of both years 1986 and 1987.

Not unexpectedly, each stick diagram shows alternating meridional current components with a similar periodicity as in the temperature records, 0 (60 days). It is most remarkable that many strong current events in $\mathrm{V}$ and $\mathrm{Q}$ appear to be $180^{\circ}$ out of phase. A visual inspection of the other neighbouring current diagrams, all approximately $200 \mathrm{~km}$ apart, shows no comparable horizontal correlation. With the exception of $V$ and $Q$, our current meter array appears to be incoherent in the period range of 50-90 days.

Current peaks of $>20 \mathrm{~cm} \mathrm{~s}^{-1}$ can be found in all these records. The averaged magnitude is about the same as in the synoptic picture of geostrophic currents already shown in Fig. 13. At mooring W4, north of the CWB, the interval of March to mid-June 1987 is remarkably quiet with a modest southward component of $0\left(3 \mathrm{~cm} \mathrm{~s}^{-1}\right)$. None of our records 


1OCT 1985 1 JAN 1986 IAPR 1 JUL 1 IOCT 1 JAN 1987 1 APA IOCT

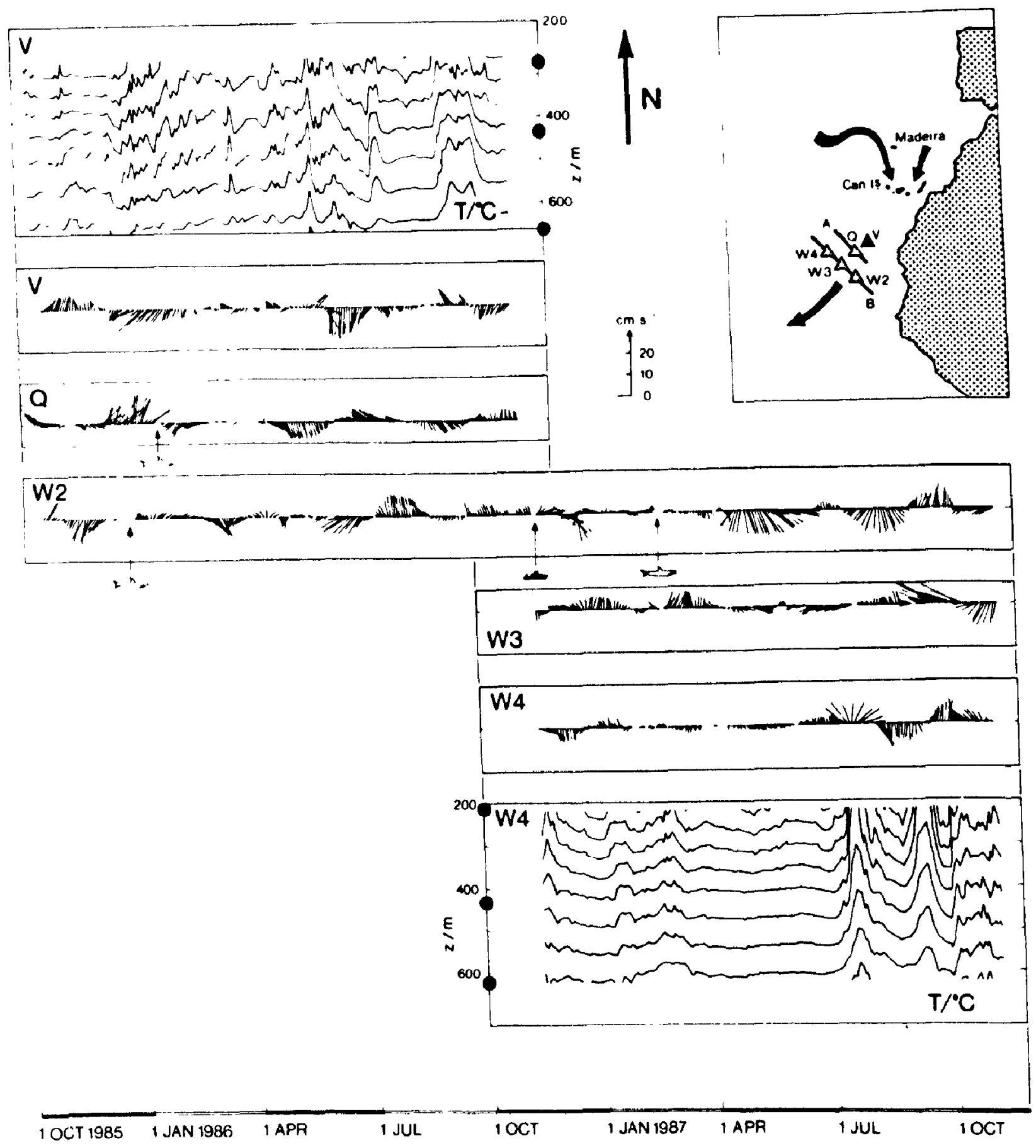

Fig. 17. Year-long current and temperature records, smoothed with a 2-day low-pass filter. from the Cape Verde Frontal Zone at a nominal depth of $4010 \mathrm{~m}$. Mooring positions were situated along the course of the Canary Current at the outer rim of the subtropical gyre. In several cases, marked by a fish symbol, the uppermost buoyancy elements were lost due to fish bite thereby decreasing the stability of the remaining mooring. Only mooring W2 was re-installed after one year. The ship symbol denotes the exchange time of W2. CTD sections A and B are noted in the inset. Isotherms were interpolated between three observational levels marked by dots. 
are long enough to allow any significant statement about seasonal variations. Further long-term current meter observations in the CWB region with emphasis on upper thermocline motions are in progress or planned for the future (ZENK et al., 1989).

\section{MEDDY BIRGIT}

With Figs 6 and 7 we discussed the hydrographic section B crossing the Cape Verde Frontal Zone. A striking feature there is the isolated, compact eddy which we sampled at Sta. $315\left(22^{\circ} 00^{\prime} \mathrm{N}, 26^{\circ} 04^{\prime} \mathrm{W}\right)$. Continuous profiles of temperature and salinity, with relatively high values in the 800-1200 dbar level, resemble the situation that ARMI and Stommel (1983) found at $26^{\circ} 32^{\prime} \mathrm{N}, 29^{\circ} 06^{\prime} \mathrm{W}$ in their beta triangle survey. In our cruise, we detected this unique distribution only once among 67 CTD stations. Armi and Stommel reported a ratio of highly saline stations to typical background stations of 1:142.

It is impossible to determine the lateral shape of the anomaly from a single station. However, on the basis of earlier studies (ARMI and ZENK, 1984; ARMI et al., 1988) and due to independent simultaneous observations (RICHARDSON et al., 1989), we are convinced that the feature has lens shape. We call this lens Meddy BIRGIT. We arbitrarily choose Sta. 306, from the northern side of the Cape Verde Frontal Zone, as a typical background station with which to compare Sta. 315 (Fig. 18). Continuous profiles were made during the downcasts of the hydrographic stations, whereas discrete bottle data were obtained on the upcasts. Because of these two independent data sources, we are confident that we measured a truly anomalous situation.

Meddy BIRGIT is of interest for at least four reasons. One is the intensity of the observed anomalies. We find temperature and salinity deviations from the background field exceeding $3.5^{\circ} \mathrm{C}$ and $0.78 \mathrm{psu}$, respectively. While these large deviations can be seen directly in the continuous profiles, we also consider rosette values for the remaining parameters. Unfortunately, at Sta. 315 we experienced technical problems with the rosette sampler below depths of $700 \mathrm{~m}$ which caused a distressing loss of data. Nonetheless, in Fig. 19 we present the discrete values of oxygen, silicate, phosphate, and nitrate concentrations

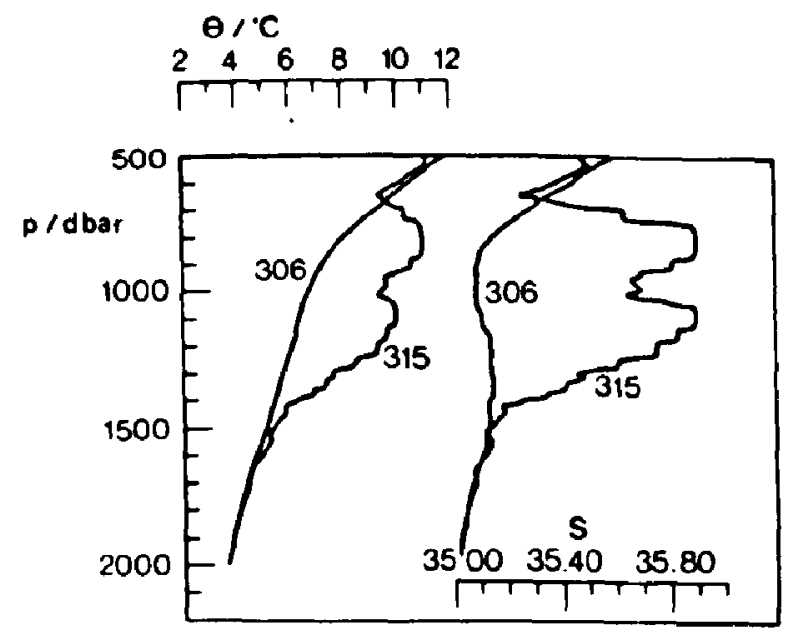

Fig. 18. Selected continuous profiles of potential temperature and salinity. Compared are a background station (306) with the singular Sta. 315. At 315 Meteor observed Meddy BIRGIT with a significant double maximum structure and several quasi-homogeneous layers. Station positions are found in Fig. 1. 

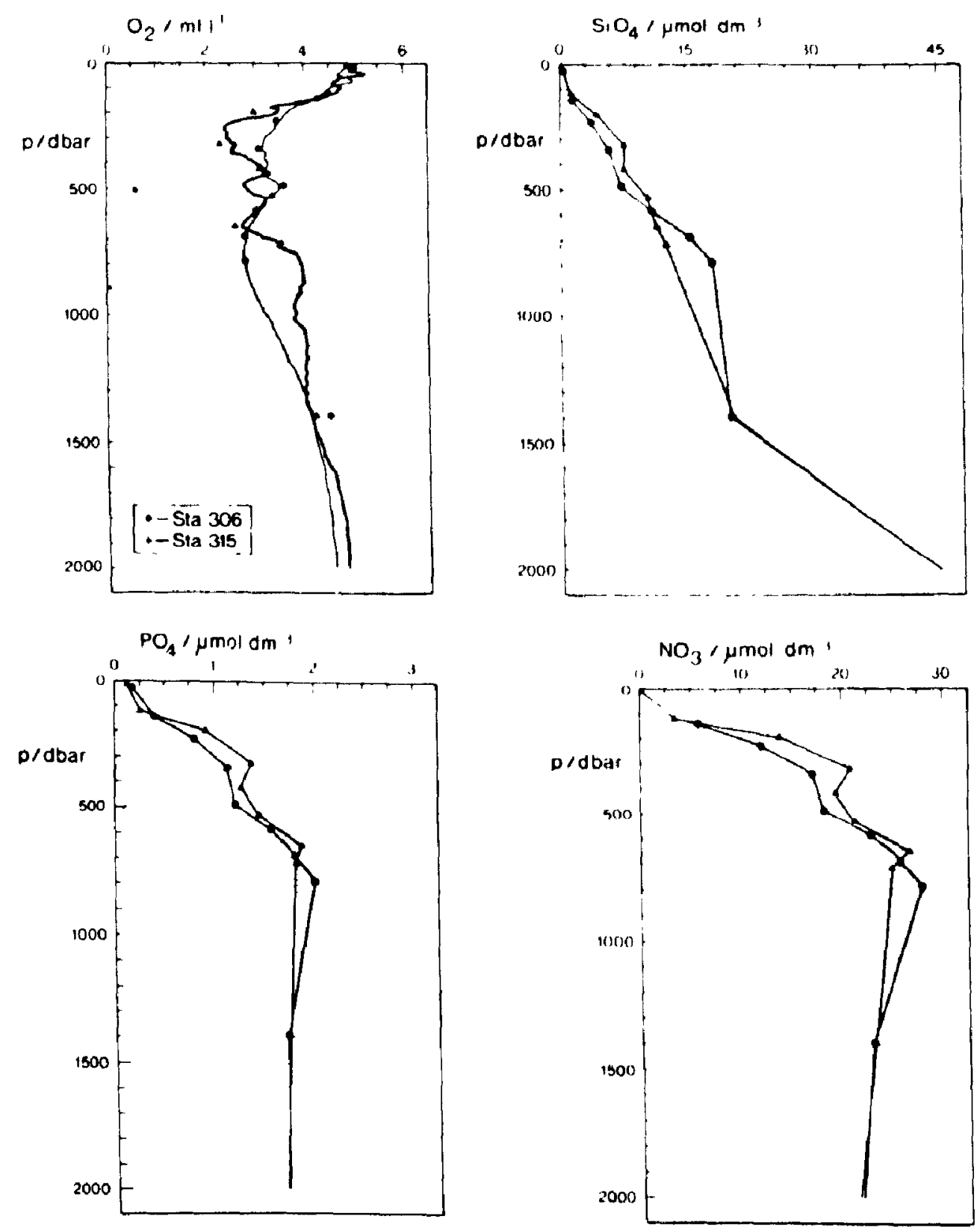

Fig. 19. Profiles of dissolved oxygen (the continuous CTD oxygen current trace has been fitted by titration values) and of nutrients from Meddy BIRGIT (315) together with the profile from background Sta. 306. Regions of excess and of deficits in the pressure range of Meddy BIRGIT are stippled.

of Meddy BIRGIT at Sta. 315 together with those of the background Sta. 306. As expected, Meddy BIRGIT has an excess in oxygen $\left(>0.6 \mathrm{ml}^{-1}\right)$ together with a deficit in silicate $\left(<0.07 \mu \mathrm{mol} \mathrm{dm}{ }^{-3}\right)$ and less pronounced deficits in phosphate and nitrate.

The large differences of all parameters from the background field are of the same order as those reported by ARMI and ZENK (1984) in the central Canary Basin, mid-way between the Azores and Canary Islands. The much larger distance of Meddy BIRGIT from the source region near Cape São Vicente (Portugal) is the second reason for its importance. This vortex was detected at about $2500 \mathrm{~km}$ distant from its source in contrast to lens 3 in ARMI and ZeNk (1984), which was "only" $1100 \mathrm{~km}$ away from its likely source. 
The third reason for our interest in this meddy lies in its vertical structure. Here we observe step-like profiles having individual, well-mixed layers several tens of metres thick, which even in the upper and lower portions of the vortex, are rare. This structure extends over a total depth range of at least $800 \mathrm{~m}$ and has vertical gradients as sharp as $\Delta T=0.85^{\circ} \mathrm{C}$ and $\Delta S=0.185$ psu per $10 \mathrm{~m}$, which are in close agreement with recent observations of Meddy SHARON (ARMI $e t$ al., 1988). These pronounced steps are indicators of doublediffusive layering and salt-fingering.

Of further interest are the intermediate minima of temperature and salinity at $950 \mathrm{~m}$, thus forming a double-maximum structure in the vertical profiles. The two maxima are associated with large homogeneous layers, $75 \mathrm{~m}$ (upper) and $116 \mathrm{~m}$ (lower) thick. This bimodal structure within the MW lens resembles earlier observations, the earliest of which came from Gieskes et al. (1970), in the region between Cape Săo Vicente and the Gettysburg Bank. Predictably, this bimodal structure is also seen in the geostrophic velocity field. A profile of geostrophic velocity relative to $2000 \mathrm{dbar}$ between Stas 314 and 315 (Fig. 20) shows mid-depth maxima of $5-6 \mathrm{~cm} \mathrm{~s}^{-1}$ associated with anticyclonic flow around the meddy. Several attempts have been made to explain the generation of meddies and to trace their histories back to the formation region somewhere in the Gulf of Cadiz. Tidal mixing (SIEDLER, 1968) and topographic control (ZENK, 1975; AMBAR and Howe, 1979) have been discussed as possible generation processes. Figure 21 displays a $\theta-S$ diagram of the Meddy Sta. 315 together with the two density levels (MAX1 and MAX2) which were found to be preferred spreading levels for MW off the Gulf of Cadiz and in the Canary Basin (ZENK, 1975). It must remain an open question as to what might have caused the observed dual structure of Meddy BIRGIT: quasi-isopycnal advection of a remote signal originating from its generation region in the Gulf of Cadiz, or local erosion, i.e. mixing of AAIW with outer rim water of the meddy. Recent Russian observations of salt lenses shows a similar bimodal structure in only one case, and it was less pronounced than that of Meddy BIRGIT (BELKIN et al., 1986).

Subsequent to our field observations of Meddy BIRGIT, a recent SOFAR float trajectory from our region of investigation has been reported. RicHARDSON et al. (1989) have found a pronounced anticyclonic helical track from their float no. 145. The trajectory

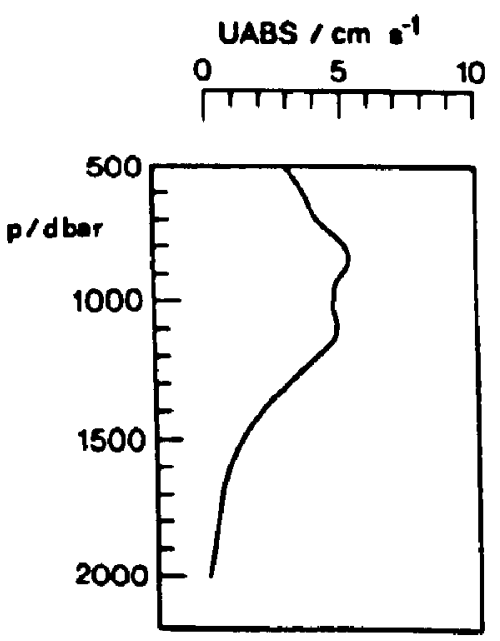

Fig. 20. Profile of geostrophic velocity relative to $2000 \mathrm{dbar}$ between neighbouring Stas 314 and 315 (Meddy BIRGIT). Note the double structure seen already in Fig. 18 is reflected in the velocity profile. 


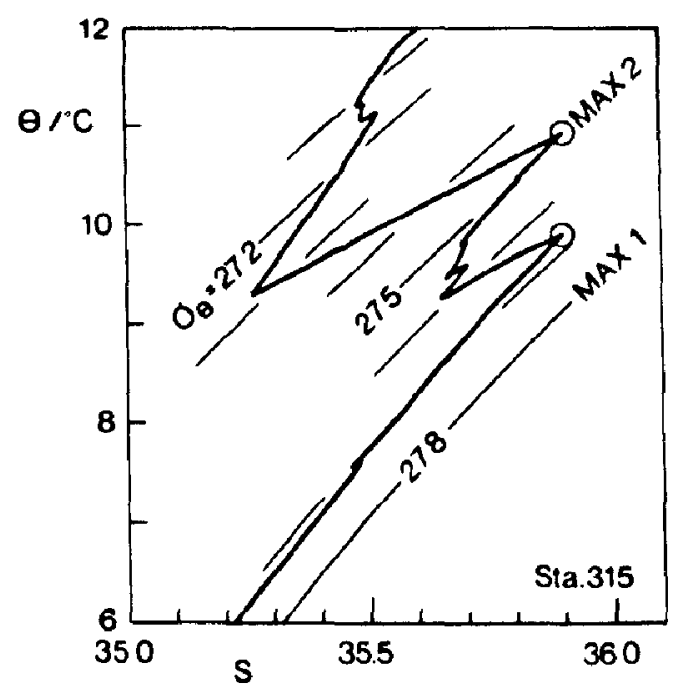

Fig. 21. Potential temperature-salinity diagram together with potential densities in terms of sigma-theta from Meddy BIRGIT (Sta. 315). Note the pronounced double maxımum structure. Similar density levels MAXI and MAX2 were found to he preferred spreading levels for Mediterranean Water in the Canary Basin (ZFNk. 1975).

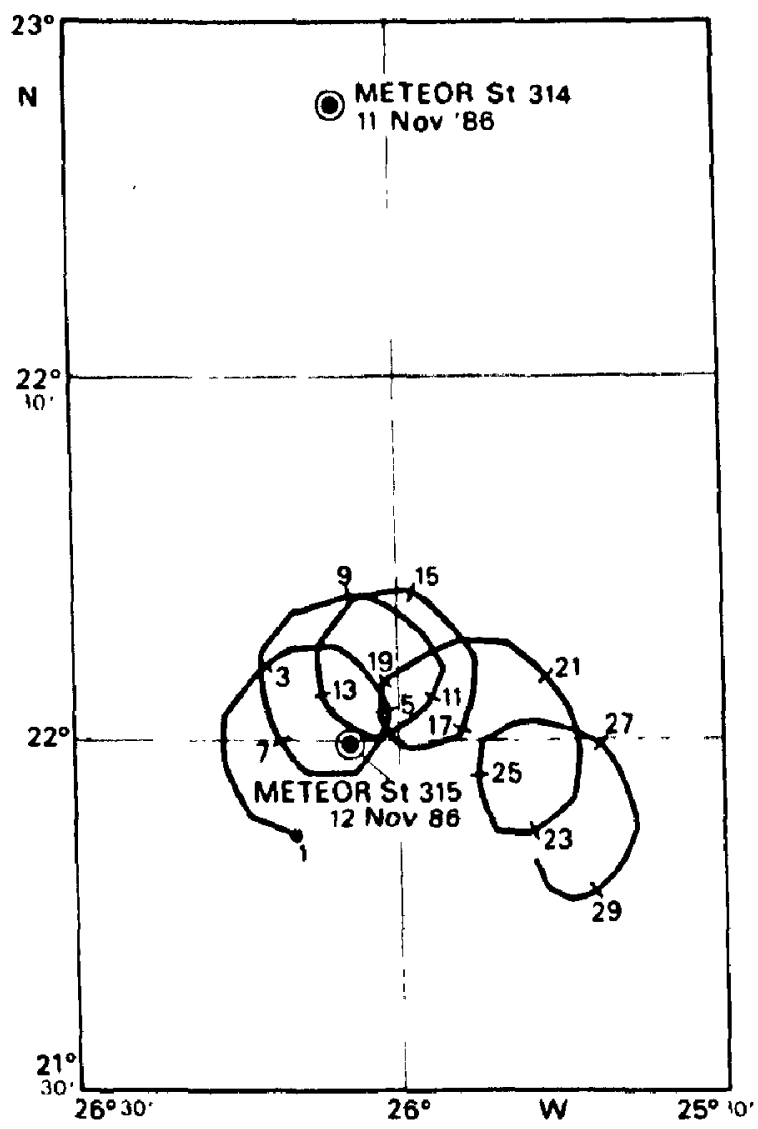

Fig. 22. Trajectory of a SOFAR float (number 145 from RichARDSON el al. , 1989), most probably within Meddy BIRGIT. (Courtesy of Dr Richardson, Woods Hole.) Tick marks denote positions on every second day from 1 to 29 November 1986.

of this float, which was launched one year earlier at a nominal depth of $1200 \mathrm{~m}$, resembles a track within Meddy SHARON reported by ARMI et al. (1988). According to RicilaRdSON et al. (1989), their float 145 was less than $5 \mathrm{~km}$ away when we occupied our Sta. 315 (Fig. 22). This fortuitous coincidence allows for a comparison of absolute and geostrophic 


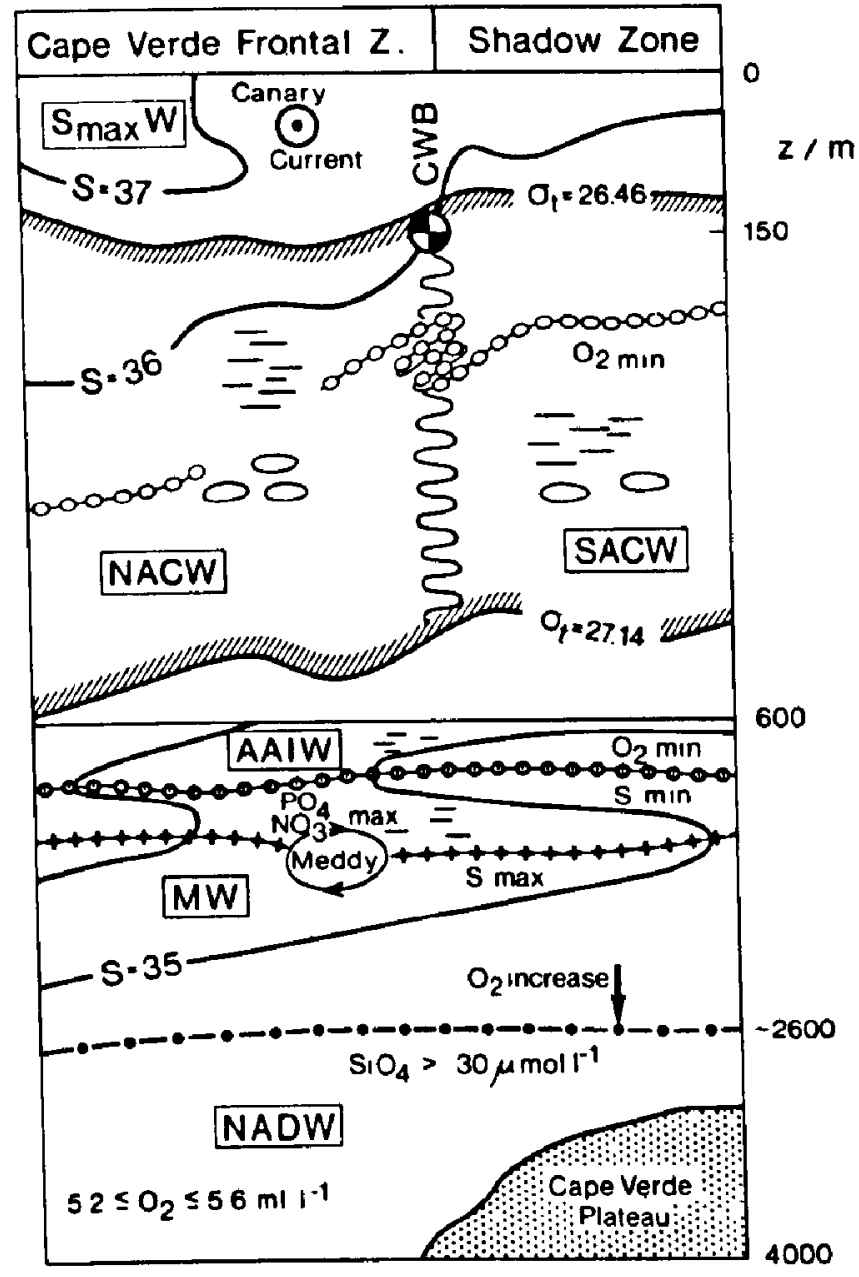

Fig. 23. Cartoon of water mass distribution in the Cape Verde Frontal Zone. Different water masses are labelled by the abbreviations enclosed in rectangular boxes. The Central Water Boundary (CWB) beneath the subtropical Salinity Maximum Water (SmaxW) acts as a separator between central water masses from the North Atlantic (NACW) and those that penetrate (HAGEN and SchemAINDA, 1989) from the South Atlantic (SACW) northeastward across the equator. Both these water masses possess layers of minimal oxygen content. Mixing across the CWB causes interleaving and isolated parcels of water masses graphically indicated by dashes and small blobs. Below the NACW/SACW front we find a second front between Mediterranean (MW) and Antarctic Intermediate Water (AAIW). Salinity and oxygen serve as markers for this internal frontal zone. Perturbations of isolated anticyclonic lenses of MW (meddies) can be part of the MW tongue. The North Atlantic Deep Water shows no front. It is labelled by increasing silicate values together with high oxygen content. This water mass occupies most of the water column in terms of volume.

speeds in the meddy. The rotational speed of float 145 was approximately $14 \mathrm{~cm} \mathrm{~s}^{-1}$, or 2-3 times higher than the geostrophic velocity shown in Fig. 20. This discrepancy may be due to several reasons: (1) the submesoscale size of Meddy BIRGIT, which is not resolvable by the $100 \mathrm{~km}$ separation of Stas 314 and 315 ; (2) the stations were not orthogonal to the flow; (3) reference depth uncertainties for the geostrophic calculations.

\section{CONCLUSION}

In this paper we have shown a quasi-synoptic picture of horizontal property distributions and vertical structures of the Cape Verde Frontal Zone. Figure 23 summarizes the 
observed water mass distributions together with their characteristic physical or chemical markers. This region, the southeastern portion of the North Atlantic subtropical gyre, is separated from the shadow zone and cross-equatorial influence by the CWB, which is a thermohaline front whose horizontal property gradients are comparable with those found in the polar frontal regions of both hemispheres.

A temperature-salinity analysis, toghether with distributions of oxygen and nutrients, are used to identify six well-marked water masses. Among them are the NACW and the SACW, which define the position of the CWB. A deeper front is identified where AAIW and MW encounter one another. The remaining two water masses are the subtropical Salinity Maximum Water, at the base of the mixed layer, and the NADW beneath the intermediate water masses. Oxygen and nutrients are used to identify the internal structure of NADW, which in terms of volume occupies most of the total water column.

North of the dual frontal system we find the Canary Current. Its geostrophic velocity distribution along cross-sections reveals a meandering, band-like current structure with characteristic separations of $100-200 \mathrm{~km}$. Year-long current meter records from an incoherent array of moorings contain typical fluctuation time scales of 50-90 days. These spatial and temporal scales are not inconsistent with scales due to baroclinic instabilities, recently investigated by HAGEN (1985) and ONKEN and KLEIN (1989).

A real surprise in our Cape Verde Frontal Zone study was the observation of a perturbation at mid-depth caused by a rotating lens of salty MW. This meddy, BIRGIT, which had double maxima in the vertical structures of temperature, salinity and oxygen, was trapped below the CWB, and it had a substantial intrusion of nearly pure SACW sitting on top of it. A strong dynamical signal of this feature, SACW over a meddy, could be traced vertically through the entire thermocline. At the surface it caused a low-saline anomaly. This purely observational result resembles recent theoretical considerations by HogG and STOMmel (1990), who studied numerically the coupling of permanent currents in the subtropical North Atlantic gyre circulation (STramma, 1984) with the advection of isolated meddies deeper down.

Acknowledgements - The work has been made possible by a grant from Deutsche Forschungsgemeinschaft (SFB 133). We have benefited from many interesting comments about the Cape Verde Frontal Zone provided by $G$. Siedler, R. Onken and numerous other colleagues and students from the IfM Kiel and abroad. One of us (W. Z.) enjoyed fruitful discussions, particularly about the double maximum problem of Meddy BIRGIT with the late Academician K. N. Fedorov. We are grateful to C. Pohl and H. Johannsen of the marine chemistry group of the IfM Kiel and to the captains and crews of F.S. Meteor and F.S. Polarstern. Thanks go to R. Peterson for careful reading of the manuscript and helpful comments. Thanks also go to P. Richardson and colleagues for providing the material for Fig. 22. With respect we acknowledge Prof. J. Reid's significant contribution to observational deep-sea research

\section{REFERENCES}

Ambar I. and M. R. Howe (1979) Observations of the Mediterrancan outflow-Il. The deep circulation in the vicinity of the Gulf of Cadiz. Deep-Sea Research, 26, 55,-568.

Armi L. and H. Stommer (1983) Four views of a portion of the North Atlantic subtropical gyre. Journal of
Physical Oceanography, 13,292-309.

ARMi L. and W. ZENk (1984) Large lenses of highly saline Mediterranean Water. Journal of Physical Oceanography, 14, 1560-1576.

Armi L., D. Herbert, N. Oakey, J. F. Price, P. L. Richardson, H. T. Rossby and B. Ruddick (1988) The history and decay of a Mediterranean salt lens. Nature, 333, 649-651. 
BArton E. D. (1987) Meanders, eddies and intrusions in the thermohaline front off Northwest Africa. Oceanologica Acta, 10, 267-282.

BARTON E. D. and P. Hughes (1982) Variability of water mass interleaving off NW Africa. Journal of Marine Research, 40, 963-984.

Bauer E. and G. Siedler (1988) The relative contributions of advection and isopycnal and diapycnal mixing below the subtropical salinity maximum. Deep-Sea Research, 35, 811-838.

Belkin I. M., M. V. Emelyanov, A. G. Kostinov and K. N. Fedorov (1986) Thermohaline structure of intrathermocline eddies. In: Intrathermocline eddies in the ocean, Shirshov Institute of Oceanography, Moscow, pp. 8-34.

EMERY W. J. and J. Meincke (1986) Global water masses: summary and review. Oceanologica Acta, 9, 383-391.

Emery W. J., W. Zenk, K. Huber, P. Rual and P. Nowlan (1987) Trends in Atlantic equatorial current variability. Deutsche Hydrographische Zeitschrift, 6, 261-276.

Fraga F., E. D. Barton and O. Llinas (1982) The concentration of nutrient salts in "pure" North and South Atlantic Central Waters. In: International Symposium on the Most Important Upwelling Areas off Western Africa (Cape Blanco and Benguela), Instituto de Investigaciones Pesquera, Barcelona 1985, Vol. 1, pp. 2536.

Gieskes J. M., J. Meincke and A. Wenk (1970) Hydrographische und chemische Beobachtungen auf einer Ankerstation im östlichen Nordatlantischen Ozean. Meteor Forschungs Ergebnisse, A, 16, 23-34.

GraBhoff K. (1976) Methods of seawater analysis, Verlag Chemie, Weinheim, 317 pp.

HAGEN E. (1985) A meandering intermediate front north-west of Cape Verde Islands. Océanographie Tropical, 20,71-83.

Hagen E. and R. Schemainda (1989) Mittlere und jahreszeitliche Strukturen im Unterstrom (UUC) des Auftriebsgebietes vor Nordwestafrika. Beiträge zur Meereskunde, Berlin, 59, 19-45.

HiLLer W. and R. H. KäSE (1983) Objective analysis of hydrographic data sets from mesoscale surveys. Berichte aus dem Institut für Meereskunde, Kiel, 116, $78 \mathrm{pp}$.

Hogg N. and H. Stommel (1990) How currents in the upper thermocline could advect Meddies deeper down. Deep-Sea Research, 37, 613-623.

Kawase M. and J. L. Sarmiento (1986) Circulation and nutrients in middepth Atlantic waters. Journal of Geophysical Research, 91, 9749-9770.

Luyten J. R., J. Pedlosky and H. Stommel (1983) The ventilated thermocline. Journal of Physical Oceanography, 13, 292-309.

Mackas D. L., K. L. Denman and A. F. Bennett (1987) Least squares multiple tracer analysis of water mass composition. Journal of Geophysical Research, 92, 2907-2918.

Manriquez M. and F. Fraga (1982) The distribution of water masses in the upwelling region off Northwest Africa in November. Rapports et Procès-Verbaux des Réunions. Conseil International pour l'Exploration de la Mer, 180, 39-47.

Mittelstaedt E. (1983) The upwelling area off Northwest Africa-A description of phenomena related to coastal upwelling. Progress in Oceanography, 12, 307-331.

Müllek T. J., G. Siedler and W. ZenK (1988) Forschungschiff Meteor, Reise Nr. 6, Atlantik 87/88, Fahrtabschnitte 1-3, Oktober-Dezember 1987. Berichte der wissenschaftlichen Leiter. Berichte aus dem Institut für Meereskunde, 184, $77 \mathrm{pp}$.

ONKEN R. and B. KLEIN (1990) Space and time scales of variability in the Cape Verde Frontal Zone. Joumal of Physical Oceanography, in press.

Piola A. R. and D. T. GeORGI (1982) Circumpolar properties of Antarctic Intermediate Water and Subantarctic Mode Water. Deep-Sea Research, 29, 687-711.

Richardson P. L., D. Walsh, L. Armi, M. Schröder and J. Price (1989) Tracking three meddies with SOFAR floats. Journal of Physical Oceanography, 19, 371-383.

SEIDLER G. (1968) Häufigkeitsverteilung von Wasserarten im Ausstrombereich von Meeresstraßen. Kieler Meeresforschungen, 24, 59-65.

SIEDLER G. (1986a) Fahrtabschnitt Las Palmas-Dakar (ANT-IV/1b). In: Die Expedition ANTARKTIS-IV mit FS "POLARSTERN" 1985/86, D. FütTERer, editor, Berichte zur Polarforschung, 32, 43-53.

SiedLer G. (1986b) Die Ventilation der Warmwassersphäre im Nordatlantik. Annalen der Meteorologie (Neue Folge), 23, 137-140.

Siedler G., H. Schmickler, T. J. Müller, H.-W. Schenke and W. Zenk (1987) Forschungsschiff Meteor, Reise $\mathrm{Nr}$. 4, Kapverden-Expedition Oktober-Dezember 1986. Berichte aus dem Institut für Meereskunde, 173. $123 \mathrm{pp}$. 
Stramma L. (1984) Geostrophic transport in the warm water sphere of the eastern subtropical North Atlantic. Journal of Marine Research, 42, 537-558.

Sverdrup H. U., M. W. Johnson and R. H. Fleming (1942) The oceans: their physics, chemistry and general biology, Prentice-Hall, Englewood Cliffs, NJ. 1087 pp.

Thiele G., W. Roether, P. Schlosser, R. Kuntz, G. Siedler and L. Stramma (1986) Baroclinic flow and transient tracer fields in the Canary-Cape-Verde Basin. Journal of Physical Oceanography, 16, 814-826.

TomczaK M. (1981) An analysis of mixing in the frontal zone of South and North Atlantic Central Water off Northwest Africa. Progress in Oceanography, 10, 173-192.

WiLlenbrinK E. (1982) Wassermassenanalyse im tropischen und subtropischen Nordostatlantik. Berichte aus dem Institut für Meereskunde, Kiel, 96, 72 pp.

ZENK W. (1975) On the origin of the intermediate double-maxima in T/S profiles from the North Atlantic. Meteor Forschungs Ergebnisse, A, 16, 23-34.

ZENK W. T. J. MüLler and G. WefER (1989) BARLAVENTO-Expedition. Reise Nr. 9. 29. Dezember 1988-17. März 1989. METEOR-Berichte, Universität Hamburg, 89-2, $238 \mathrm{~S}$. 